\title{
Renal function in patients with non-dialysis chronic kidney disease receiving intravenous ferric carboxymaltose: an analysis of the randomized FIND-CKD trial
}

lain C. Macdougall ${ }^{1 *}$, Andreas H. Bock², Fernando Carrera ${ }^{3}$, Kai-Uwe Eckardt ${ }^{4}$, Carlo Gaillard ${ }^{5}$, David Van Wyck ${ }^{6}$, Yvonne Meier ${ }^{7}$, Sylvain Larroque ${ }^{7}$, Simon D. Roger ${ }^{8}$ and on behalf of the FIND-CKD Study investigators

\begin{abstract}
Background: Preclinical studies demonstrate renal proximal tubular injury after administration of some intravenous iron preparations but clinical data on renal effects of intravenous iron are sparse.

Methods: FIND-CKD was a 56-week, randomized, open-label, multicenter study in which patients with non-dialysis dependent chronic kidney disease (ND-CKD), anemia and iron deficiency without erythropoiesis-stimulating agent therapy received intravenous ferric carboxymaltose (FCM), targeting either higher (400-600 $\mu \mathrm{g} / \mathrm{L})$ or lower (100-200 $\mu \mathrm{g} / \mathrm{L})$ ferritin values, or oral iron.

Results: Mean (SD) eGFR at baseline was 34.9 (11.3), 32.8 (10.8) and 34.2 (12.3) $\mathrm{mL} / \mathrm{min} / 1.73 \mathrm{~m}^{2}$ in the high ferritin FCM $(n=97)$, low ferritin FCM $(n=89)$ and oral iron $(n=167)$ groups, respectively. Corresponding values at month 12 were 35.6 (13.8), 32.1 (12.7) and $33.4(14.5) \mathrm{mL} / \mathrm{min} / 1.73 \mathrm{~m}^{2}$. The pre-specified endpoint of mean (SE) change in eGFR from baseline to month 12 was $+0.7(0.9) \mathrm{mL} / \mathrm{min} / 1.73 \mathrm{~m}^{2}$ with high ferritin FCM ( $p=0.15$ versus oral iron), -0.9 (0.9) $\mathrm{mL} / \mathrm{min} / 1.73 \mathrm{~m}^{2}$ with low ferritin FCM ( $p=0.99$ versus oral iron) and $-0.9(0.7) \mathrm{mL} / \mathrm{min} / 1.73 \mathrm{~m}^{2}$ with oral iron. No significant association was detected between quartiles of FCM dose, change in ferritin or change in TSAT versus change in eGFR. Dialysis initiation was similar between groups. Renal adverse events were rare, with no indication of between-group differences.
\end{abstract}

Conclusion: Intravenous FCM at doses that maintained ferritin levels of $100-200 \mu \mathrm{g} / \mathrm{L}$ or $400-600 \mu \mathrm{g} / \mathrm{L}$ did not negatively impact renal function (eGFR) in patients with ND-CKD over 12 months versus oral iron, and eGFR remained stable. These findings show no evidence of renal toxicity following intravenous FCM over a 1-year period.

Trial registrations: ClinicalTrials.gov NCT00994318 (first registration 12 October 2009).

Keywords: Chronic kidney disease, Ferinject, Ferric carboxymaltose, eGFR, Intravenous, Renal function

\footnotetext{
* Correspondence: iain.macdougall@nhs.net

'Department of Renal Medicine, King's College Hospital, Denmark Hill,

London SE5 9RS, UK

Full list of author information is available at the end of the article
} 


\section{Background}

The use of iron therapy to manage renal anemia in patients with chronic kidney disease (CKD) has increased significantly in recent years [1], partly in response to concerns about the safety of erythropoiesisstimulating agent (ESA) therapies [2, 3]. Randomized trials have shown intravenous (IV) iron therapy to be more effective than oral iron in terms of replenishing depleted iron stores and improving anemia in patients on dialysis [4-6]. In non-dialysis dependent CKD (NDCKD), trials have confirmed the benefits of IV versus oral iron therapy but have typically been no longer than 8 weeks in duration [7-11]. Recently, the randomized 56-week FIND-CKD study compared IV ferric carboxymaltose (FCM) versus oral iron in patients with ND-CKD, anemia, and iron deficiency not receiving ESA therapy [12]. Intravenous FCM targeting a ferritin level of $400-600 \mu \mathrm{g} / \mathrm{L}$ delayed and/or reduced the need for other anemia management (including ESAs) significantly at 1 year compared to patients receiving oral iron, and the hematopoietic response was more rapid.

However, concerns exist about the potential renal toxicity of IV iron therapy [13]. Rapid release of large amounts of iron into the bloodstream could generate 'free' iron in the circulation (non-transferrin bound iron, NTBI) which may promote oxidative stress [14, 15]. Some IV iron complexes such as ferric gluconate contain weakly-bound iron that is released readily and quickly [15]. In contrast, animal models have shown, that oxidative stress does not increase with more stable IV iron complexes such as FCM [16-18]. Clinical evidence relating to a possible effect of IV iron therapy on renal function is limited. Single-dose and short-term (5-week) studies from one center have indicated that iron sucrose may induce renal injury mediated by oxidative stress and inflammation [19-23]. However, the recently published REVOKE study, which randomized patients with NDCKD to IV iron sucrose or oral iron, showed neither a difference in renal function decline (based on GFR measured by iothalamate clearance) nor in proteinuria during follow-up lasting up to 2 years [24]. Confirmatory data are clearly important.

The FIND-CKD trial included protocol-specified monitoring of renal function in over 600 patients with ND-CKD, based on estimated GFR (eGFR), throughout the 1-year study [25]. Data were analyzed to compare renal outcomes in patients randomized to IV FCM using two different dosing regimens aiming for different target ferritin concentrations, with those in patients receiving oral iron.

\section{Methods}

\section{Study design}

FIND-CKD was a 56-week, open-label, multicenter, prospective, randomized, three-arm study undertaken during December 2009 to January 2012 at 193 nephrology centers in 20 countries (ClinicalTrials.gov NCT00994318) [25].

\section{Patient population}

Adult patients ( $\geq 18$ years) with ND-CKD were eligible for inclusion if (a) at least one $\mathrm{Hb}$ level was between 9 and $11 \mathrm{~g} / \mathrm{dL}$ within 4 weeks of randomization, (b) any ferritin level was $<100 \mu \mathrm{g} / \mathrm{L}$, or $<200 \mu \mathrm{g} / \mathrm{L}$ with transferrin saturation (TSAT) $<20 \%$, within 4 weeks of randomization, (c) eGFR was $\leq 60 \mathrm{~mL} / \mathrm{min} / 1.73 \mathrm{~m}^{2}$ (four-variable Modification of Diet in Renal Disease [MDRD-4] equation [26]), the prior rate of eGFR loss was $\leq 12 \mathrm{~mL} / \mathrm{min} /$ $1.73 \mathrm{~m}^{2} /$ year and predicted eGFR at 12 months based on previous decline was $\geq 15 \mathrm{~mL} / \mathrm{min} / 1.73 \mathrm{~m}^{2}$, and (d) no ESA had been administered within 4 months prior to randomization. Estimates of prior eGFR loss were based on at least two values over at least 4 weeks prior to randomization, and preferably three values over at least 3 months.

Key exclusion criteria included current dialysis, anticipated dialysis or transplantation during the study, anemia due to reasons other than iron deficiency, a documented history of discontinuing oral iron products due to significant gastrointestinal distress, known active infection, C-reactive protein $>20 \mathrm{mg} / \mathrm{L}$, overt bleeding, active malignancy, chronic liver disease, concomitant New York Heart Association Class IV heart failure and poorly controlled hypertension $(>160 \mathrm{mmHg}$ systolic pressure or $>100 \mathrm{mmHg}$ diastolic pressure).

\section{Randomization and intervention}

Eligible patients were randomized centrally via a central interactive voice-response system in a 1:1:2 ratio to high ferritin FCM, low ferritin FCM or oral iron. The dose of FCM (Ferinject, Vifor International, St Gallen, Switzerland) in the high ferritin and low ferritin FCM groups was adjusted to target a ferritin level of 400 $-600 \mu \mathrm{g} / \mathrm{L}$ and $100-200 \mu \mathrm{g} / \mathrm{L}$, respectively. An initial single dose was administered on day 0: $1000 \mathrm{mg}$ iron as FCM in the high ferritin FCM group (500 $\mathrm{mg}$ iron on days 0 and 7 in patients weighing $\leq 66 \mathrm{~kg}$ ) and $200 \mathrm{mg}$ iron as FCM in the low ferritin FCM group if ferritin was $<100 \mu \mathrm{g} / \mathrm{L}$. During weeks 4 to 48 , FCM was administered every 4 weeks in the high ferritin FCM group at a dose of $500 \mathrm{mg}$ iron if ferritin was in the range 200 to $<400 \mu \mathrm{g} / \mathrm{L}$, and at a dose of $1000 \mathrm{mg}$ iron if ferritin was $<200 \mu \mathrm{g} / \mathrm{L}$, and in the low ferritin FCM group at a dose of $200 \mathrm{mg}$ iron if ferritin was $<100 \mu \mathrm{g} / \mathrm{L}$. In both groups, dosing was withheld if TSAT was $\geq 40 \%$. Oral iron therapy consisted of commercially-available ferrous sulfate at a dose of $304 \mathrm{mg}$ (100 mg of iron) twice daily to week 52. During the first 8 weeks after randomization, 
patients were not to receive ESAs, blood transfusion or any anemia therapy other than study drug unless there was an absolute requirement, after which ESAs and other therapies were permitted according to local practice if the $\mathrm{Hb}$ was $<10 \mathrm{~g} / \mathrm{dL}$.

\section{Assessment of renal function}

Renal function was assessed by eGFR, with values calculated locally and provided by the study sites using the MDRD-4 formula [26]. Estimated GFR was recorded at baseline and at every 3 months throughout the 12-month study period. The change in eGFR from baseline to the end of the study was a prespecified secondary endpoint of the trial. GFR was estimated by the MDRD-4 formula [26]. As a post hoc sensitivity analysis, GFR was also estimated by the creatinine-based Chronic Kidney Disease Epidemiology Collaboration (CKD-EPI) formula [27]. CKDEPI values were calculated centrally using locallymeasured serum creatinine levels. The percentage of patients starting dialysis was a further pre-specified secondary endpoint.

\section{Statistical analysis}

All analyses of renal function were exploratory. Analysis of covariance (ANCOVA) modeling was used to compare the change in eGFR values from baseline to month 12 between groups based on least square (LS) mean values using a repeated fixed effects model with treatment, visit and pooled country as factors, baseline eGFR as covariate, and treatment-by-visit as an interaction. Change in eGFR at month 12 was summarized in subpopulations of patients according to age $(\leq$ or $>$ median), gender, body mass index (BMI, $\leq$ or $>$ median), baseline systolic and diastolic blood pressure ( $\leq$ or $>$ median), mean arterial pressure and history of diabetes at baseline. Furthermore, a multivariate analysis including demographics and baseline characteristics (age, gender, BMI, systolic and diastolic blood pressure, diabetic status, prior use of angiotensin converting enzyme [ACE] inhibitor and angiotensin II receptor blocker [ARB] medications) was performed to check for potential confounding effect and best impacting factor on the analysis of treatment effect.

For the proportion of patients requiring dialysis, logistic regression analyses were performed and odds ratios (ORs) were used to compare treatment groups.

Post hoc, absolute eGFR values and the change in eGFR from baseline to month 12 were analyzed according to (i) quartiles of total FCM dose throughout the 12-month study using pooled data from both FCM treatment groups (ii) quartiles of change in ferritin level from baseline to month 12 across all patients (iii) quartiles of change in TSAT level from baseline to month 12 across all patients.

Renal function was analyzed in the intention-to-treat (ITT) population, comprising all patients who received at least one dose of randomized treatment and who attended at least one post-baseline visit. Patients were excluded from the analysis of change in eGFR to month 12 if (a) they reached the primary event before month 12 (i.e. received alternative management for anemia) or (b) the randomized treatment regimen was permanently discontinued before month 12. Within this cohort, calculations for the change in eGFR, ferritin and TSAT from baseline to month 12 were based on the subpopulations of patients who had values available at both time points.

Adverse events were analyzed in the safety population, comprising all patients who received at least one dose of randomized study drug.

All statistical analyses were performed using SAS Version 9.3 (SAS Institute Inc. SAS/STAT, Cary, NC, USA).

\section{Results}

\section{Study population}

In total, 613 patients were randomized and included in the ITT population. Estimated GFR was measured at baseline in all patients. Of 519 patients who completed the study, 166 patients had started another anemia management and/or stopped the randomized study regimen before month 12, and were excluded from analyses. Thus eGFR values at both baseline and month 12 were analyzed in 353 patients $(97,89$ and 167 patients in the high ferritin FCM group, the low ferritin FCM group and the oral iron group, respectively). These patients were included in the current analysis. The demographics and other characteristics of this subpopulation (Table 1) did not differ from the total ITT population (Additional file 1: Table S1) and were comparable between groups.

Baseline eGFR in this subpopulation of patients was similar between treatment groups (Table 2) and did not show any relevant differences to baseline values in the total ITT population (mean [SD] 32.8 [11.7] $\mathrm{mL} /$ $\min / 1.73 \mathrm{~m}^{2}, \quad 31.5 \quad[10.7] \mathrm{mL} / \mathrm{min} / 1.73 \mathrm{~m}^{2}$ and 32.3 [11.6] $\mathrm{mL} / \mathrm{min} / 1.73 \mathrm{~m}^{2}$, respectively, in the high ferritin FCM, low ferritin FCM and oral iron groups).

Four patients in this cohort of 353 patients were included against protocol with baseline eGFR $>60 \mathrm{~mL} / \mathrm{min} / 1.73 \mathrm{~m}^{2}$ : one high ferritin FCM patient $\left(63 \mathrm{~mL} / \mathrm{min} / 1.73 \mathrm{~m}^{2}\right)$, one low ferritin FCM patient $\left(61 \mathrm{~mL} / \mathrm{min} / 1.73 \mathrm{~m}^{2}\right)$ and two patients in the oral iron group (66 and $77 \mathrm{~mL} / \mathrm{min} /$ $1.73 \mathrm{~m}^{2}$ ). Three patients in the oral iron group contravened the exclusion criterion that eGFR loss was to be no more than $12 \mathrm{~mL} / \mathrm{min} / 1.73 \mathrm{~m}^{2}$ per year. 
Table 1 Baseline characteristics for patients with eGFR values at baseline and month 12

\begin{tabular}{|c|c|c|c|}
\hline & $\begin{array}{l}\text { High ferritin } \\
\text { FCM }(n=97)\end{array}$ & $\begin{array}{l}\text { Low ferritin } \\
\text { FCM }(n=89)\end{array}$ & $\begin{array}{l}\text { Oral iron } \\
(n=167) \\
\end{array}$ \\
\hline Age, years & $69.3(12.9)$ & $69.0(12.1)$ & $69.6(12.7)$ \\
\hline Female gender, n (\%) & $61((62.9)$ & $56(62.9)$ & $106(63.5)$ \\
\hline White race, n (\%) & $93(95.9)$ & $83(93.3)$ & $159(95.2)$ \\
\hline Body mass index, $\mathrm{kg} / \mathrm{m}^{2}$ & $30.5(6.8)$ & $30.0(5.3)$ & $29.4(5.4)$ \\
\hline History of diabetes, n (\%) & $61(62.9)$ & $59(66.3)$ & $106(63.5)$ \\
\hline $\begin{array}{l}\text { Endogenous } \\
\text { erythropoietin, } \mathrm{mIU} / \mathrm{mL}\end{array}$ & $29.4(24.6)$ & $29.6(27.4)$ & $26.3(20.9)$ \\
\hline $\mathrm{Hb}, \mathrm{g} / \mathrm{dL}$ & $10.4(0.7)$ & $10.5(0.9)$ & $10.7(0.6)$ \\
\hline Ferritin, $\mu \mathrm{g} / \mathrm{L}$ & 54.2 94.9) & $45.8(44.3)$ & $52.4(39.9)$ \\
\hline TSAT, \% & $16.3(20.2)$ & $14.9(7.5)$ & $14.8(7.0)$ \\
\hline C-reactive protein, mg/L & $7.4(13.4)$ & $5.7(5.9)$ & $5.3(6.5)$ \\
\hline $\begin{array}{l}\text { ACE inhibitor therapy } \\
\text { prior to study entry, } \\
n(\%)^{\mathrm{a}}\end{array}$ & $32(33.0)$ & $37(41.6)$ & $69(41.3)$ \\
\hline $\begin{array}{l}\text { Angiotensin II antagonist } \\
\text { therapy prior to study } \\
\text { entry, } \mathrm{n}(\%)^{\mathrm{b}}\end{array}$ & $41(42.3)$ & $33(37.1)$ & $77(46.1)$ \\
\hline
\end{tabular}

Continuous variables are shown as mean (SD)

$A C E$ angiotensin converting enzyme inhibitor, FCM ferric carboxymaltose, $\mathrm{Hb}$ hemoglobin, TSAT transferrin saturation

${ }^{a}$ Includes patients receiving ACE inhibitor combinations

${ }^{\mathrm{b}}$ Includes patients receiving angiotensin II antagonist combinations

\section{Change in renal function}

Values for eGFR showed no change in any of the three treatment groups throughout the 12-month study (Fig. 1). At month 12, mean (SD) eGFR was 35.6 (13.8) $\mathrm{mL} / \mathrm{min} / 1.73 \mathrm{~m}^{2}, 32.1(12.7) \mathrm{mL} / \mathrm{min} / 1.73 \mathrm{~m}^{2}$ and 33.4 (14.5) $\mathrm{mL} / \mathrm{min} / 1.73 \mathrm{~m}^{2}$, respectively. The pre-defined endpoint of change from baseline to month 12 was +0.7 (0.9) $\mathrm{mL} / \mathrm{min} / 1.73 \mathrm{~m}^{2}$ in the high ferritin FCM group, $-0.9(0.9) \mathrm{mL} / \mathrm{min} / 1.73 \mathrm{~m}^{2}$ in the low ferritin FCM group and $-0.9(0.7) \mathrm{mL} / \mathrm{min} / 1.73 \mathrm{~m}^{2}$ in the oral iron group (least square [LS] mean $[\mathrm{SE}]$ values). There were no significant differences in the change from baseline to month 12 for either FCM group versus oral iron $(p=$ 0.15 for the high ferritin group, $p=0.99$ for the low ferritin FCM group). The mean (SE) percentage change in eGFR was $3.1(2.6) \%$ in the high ferritin FCM group ( $p$ $=0.098$ versus oral iron) (Table 2 ).

As a sensitivity analysis, eGFR was also calculated using the CKD-EPI formula. Serum creatinine values were provided for central calculation of CKD-EPI values in 82, 68 and 137 patients in the high ferritin FCM, low ferritin FCM and oral iron groups, respectively. Based on the CKD-EPI formula, there was a significant increase in eGFR from baseline to month 12 for the high ferritin FCM group versus oral iron $(p=0.012)$ (Table 2).

When the change in eGFR from baseline to month 12 was assessed in subpopulations of patients according to
Table 2 Estimated GFR (eGFR) for patients with eGFR values at baseline and month 12

\begin{tabular}{|c|c|c|c|}
\hline & $\begin{array}{l}\text { High ferritin } \\
\text { FCM }(n=97)\end{array}$ & $\begin{array}{l}\text { Low ferritin } \\
\text { FCM }(n=89)\end{array}$ & $\begin{array}{l}\text { Oral iron } \\
(n=167)\end{array}$ \\
\hline \multicolumn{4}{|l|}{$\begin{array}{l}\text { eGFR at baseline (MDRD), } \\
\mathrm{mL} / \mathrm{min} / 1.73 \mathrm{~m}^{2}\end{array}$} \\
\hline Mean (SD) & $34.9(11.3)$ & $32.8(10.8)$ & $34.2(12.3)$ \\
\hline$\geq 60, n(\%)$ & $1(1.0)$ & $1(1.1)$ & $3(1.8)$ \\
\hline 30 to $<60, \mathrm{n}(\%)$ & $62(63.9)$ & $51(57.3)$ & $101(60.5)$ \\
\hline 15 to $<30, \mathrm{n}(\%)$ & $34(35.1)$ & $37(41.6)$ & $60(35.9)$ \\
\hline$<15, \mathrm{n}(\%)$ & 0 & 0 & $3(1.8)$ \\
\hline \multicolumn{4}{|l|}{$\begin{array}{l}\text { eGFR at month } 12 \text { (MDRD), } \\
\mathrm{mL} / \mathrm{min} / 1.73 \mathrm{~m}^{2}\end{array}$} \\
\hline Mean (SD) & $35.6(13.8)$ & $32.1(12.7)$ & $33.4(14.5)$ \\
\hline$\geq 60, \mathrm{n}(\%)$ & $7(7.2)$ & $4(4.5)$ & $7(4.2)$ \\
\hline 30 to $<60, \mathrm{n}(\%)$ & $54(55.7)$ & $40(44.9)$ & $83(49.7)$ \\
\hline 15 to $<30, \mathrm{n}(\%)$ & $32(33.0)$ & $39(43.8)$ & $65(38.9)$ \\
\hline$<15, \mathrm{n}(\%)$ & $4(4.1)$ & $6(6.7)$ & $12(7.2)$ \\
\hline $\begin{array}{l}\text { Change from baseline to } \\
\text { month } 12, \mathrm{LS} \text { mean (SE) } \\
\text { (MDRD), } \mathrm{mL} / \mathrm{min} / 1.73 \mathrm{~m}^{2}\end{array}$ & $0.7(0.9)$ & $-0.9(0.9)$ & $-0.9(0.7)$ \\
\hline$p$ value for change vs oral iron ${ }^{a}$ & 0.15 & 0.99 & Reference \\
\hline $\begin{array}{l}\text { Relative change from baseline } \\
\text { to month } 12, \text { LS mean (SE) } \\
\text { (MDRD), \% }\end{array}$ & $3.1(2.6)$ & $-2.4(2.7)$ & $-2.2(2.0)$ \\
\hline$p$ value for change vs oral iron ${ }^{a}$ & 0.098 & 0.95 & Reference \\
\hline $\begin{array}{l}\text { eGFR (CKD-EPI) } \\
\mathrm{mL} / \mathrm{min} / 1.73 \mathrm{~m}^{2}\end{array}$ & $n=82$ & $n=68$ & $n=137$ \\
\hline Mean (SD) at baseline & $33.5(11.9)$ & $32.0(11.8)$ & $32.5(13.4)$ \\
\hline Mean (SD) at month 12 & $34.8(13.1)$ & $31.1(13.5)$ & $31.0(14.8)$ \\
\hline $\begin{array}{l}\text { Change, LS mean (SE), } \\
\mathrm{mL} / \mathrm{min} / 1.73 \mathrm{~m}^{2}\end{array}$ & $1.3(1.0)$ & $-1.2(1.0)$ & $-1.7(0.7)$ \\
\hline$p$ value for change vs oral iron ${ }^{a}$ & 0.012 & 0.68 & Reference \\
\hline
\end{tabular}

eGFR was estimated by the MDRD-4 equation [27] at the local laboratory $\mathrm{Cl}$ confidence interval, CKD-EPI Chronic Kidney Disease Epidemiology Collaboration (CKD-EPI), eGFR estimated GFR, FCM ferric carboxymaltose, LS least squares, MDRD Modification of Diet in Renal Disease, $S E$ standard error ${ }^{a}$ Analysis of covariance analysis based on least square mean values, using repeated measures

age, gender, BMI, presence/absence of diabetes, systolic and diastolic blood pressure and mean arterial pressure, no apparent influence of treatment group was observed (Additional file 2: Table 2).

\section{Change in renal function according to FCM dose}

The mean (SD) total dose of FCM 2793 (932) mg iron in the high ferritin group and 1205 (626) mg iron in the low ferritin group among patients with eGFR data available at baseline and month 12 (excluding patients who started another anemia therapy or permanently discontinued study treatment.) The change in eGFR from baseline to month 12 showed 


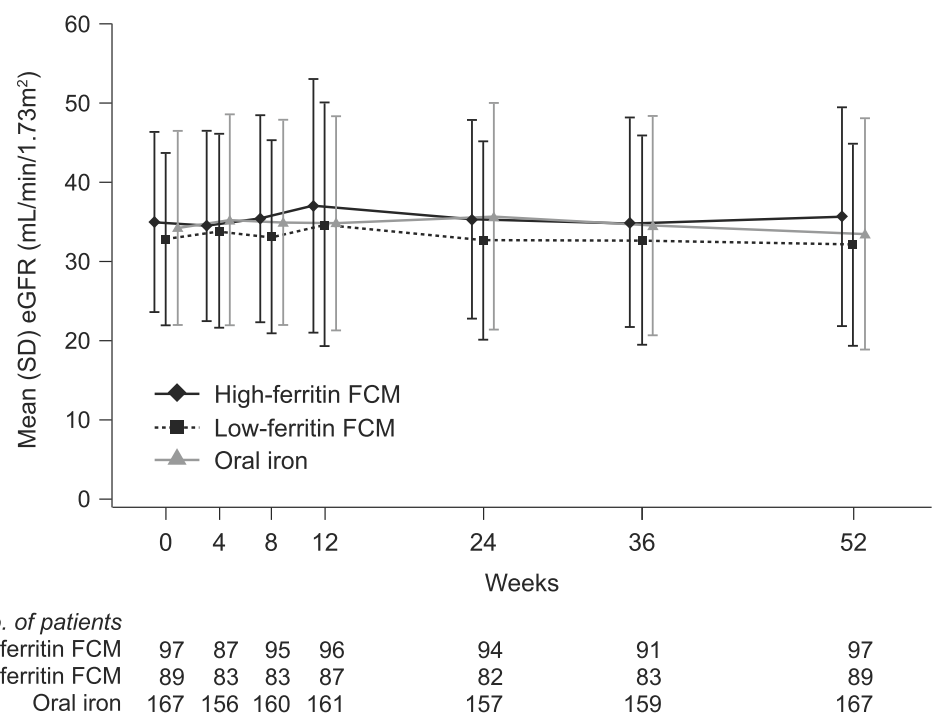

Fig. 1 Estimated GFR to month 12 according to treatment group in patients with eGFR values at baseline and month 12. Values are shown as mean (SD). FCM, ferric carboxymaltose; eGFR, estimated GFR

no association with total FCM dose when plotted individually for patients in either the high ferritin FCM or low ferritin FCM groups (Additional file 3: Figure S1). Using pooled data from both FCM groups, the change in eGFR to month 12 was analyzed by quartiles of total FCM dose (Fig. 2a).

The multivariate model indicated that age $(p=0.007)$, systolic blood pressure $(p=0.004)$, diabetic status $(p=$ $0.058)$ and prior use of ACE inhibitor therapy $(p=0.054)$ exerted an impact on the change in eGFR (MDRD) to month 12. When these factors were added into the repeated measures model over time, the least square mean values for treatment effect were similar for the high ferritin FCM, low ferritin FCM and oral iron groups $\left(0.7,-0.8\right.$ and $-0.9 \mathrm{~mL} / \mathrm{min} / 1.73 \mathrm{~m}^{2}$, respectively; $p=0.14$ for high ferritin FCM versus oral iron, $p=0.92$ for low ferritin FCM versus oral iron). When repeated using the CKD-EPI equation to estimate GFR, only age $(p=0.042)$ and systolic blood pressure $(p=0.004)$ were found to influence the change in eGFR to month 12 . Inclusion of these two factors in the repeated measure model produced LS mean values of $1.3 \mathrm{~mL} / \mathrm{min} / 1.73 \mathrm{~m}^{2}$ for the high ferritin FCM group, $-1.1 \mathrm{~mL} / \mathrm{min} / 1.73 \mathrm{~m}^{2}$ for the low ferritin FCM group and $-1.7 \mathrm{~mL} / \mathrm{min} /$ $1.73 \mathrm{~m}^{2}$ for the oral iron group $(p=0.010$ versus high ferritin FCM, $p=0.613$ versus low ferritin FCM).

\section{Change in renal function according to iron status}

Mean ferritin levels were within the pre-specified target ranges from week 12 to the end of the study in both of the FCM treatment arms (Additional file 4: Figure S2a).
At month 12, the mean (SD) change in ferritin from baseline was 455 (116), 81 (59) and 139 (111) $\mu \mathrm{g} / \mathrm{L}$ in the high ferritin FCM, low ferritin FCM and oral iron groups, respectively, among patients with eGFR available at baseline and month 12. The change in eGFR from baseline to month 12 showed no significant association with the change in ferritin over the same period when analyzed by quartiles (Fig. 2b).

TSAT levels to month 12 are shown in Additional file 4: Figure S2b. As observed for ferritin levels, the change in eGFR showed no significant differences between quartiles of change in TSAT (Fig. 2c).

\section{Renal events}

In total, 16/613 patients in the ITT population (2.6\%) progressed to dialysis by month 12 ( 5 high ferritin FCM, 1 low ferritin FCM, 10 oral iron). There was no significant difference in the risk of dialysis for either FCM group versus oral iron: OR 1.01 (95\% CI 0.34, 3.00; $p=$ $0.99)$ for the high ferritin FCM group and OR 0.20 (95\% CI $0.03,1.56 ; p=0.12$ ) for the low ferritin group. No patient underwent renal transplantation.

Rates of adverse events and serious adverse events related to renal function were low with no indication of clinically relevant differences between treatment groups (Additional file 5: Table S3).

\section{Discussion}

Results from the randomized FIND-CKD trial show that compared to oral iron, administration of IV FCM in doses that maintain ferritin levels of $100-200 \mu \mathrm{g} / \mathrm{L}$ or 


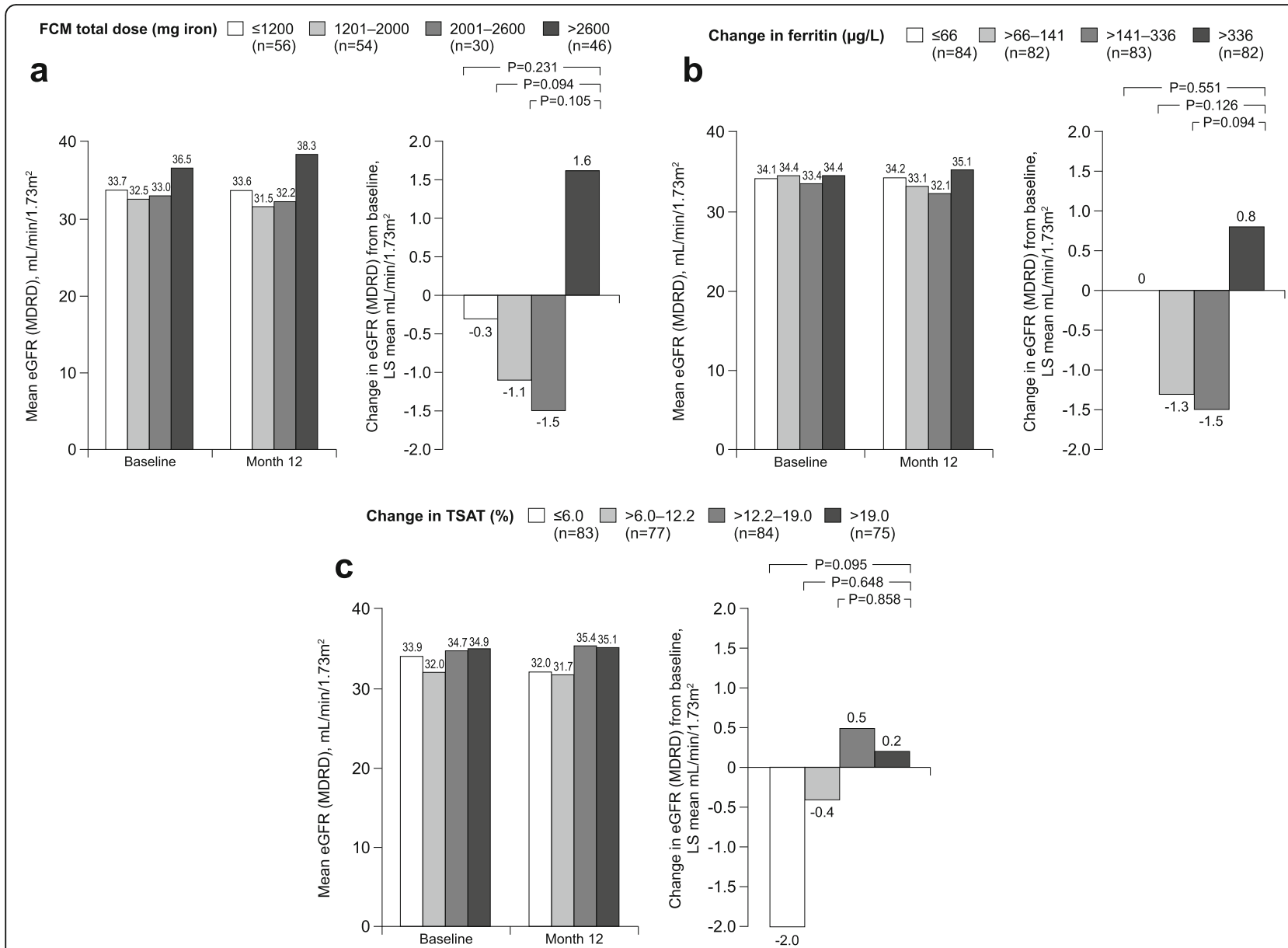

Fig. 2 Absolute estimated glomerular filtration rate (eGFR) and change in eGFR from baseline to month 12 according to quartiles of (a) total ferric carboxymaltose (FCM) dose to month 12 in patients randomized to high ferritin FCM or low ferritin FCM (b) change in ferritin from baseline to month 12 across all treatment groups and (c) change in transferrin saturation (TSAT) from baseline at month 12 across all treatment groups. Data are shown for patients with eGFR values at baseline and month 12. Change in eGFR is shown as least squares (LS) mean values. MDRD, Modification of Diet in Renal Disease

$400-600 \mu \mathrm{g} / \mathrm{L}$ does not negatively impact renal function, as determined by eGFR, in patients with ND-CKD after 1 year. Mean eGFR remained stable during the study in both the FCM treatment groups, and the change in eGFR to 1 year did not differ from that seen in patients treated with oral iron therapy, either on univariate or multivariate analysis. These findings, calculated using the pre-specified MDRD-4 formula, were confirmed when GFR was estimated by the more recently developed CKDEPI formula [28]. Indeed, if anything, there was an increase in eGFR in the patients in the high-ferritin FCM arm compared to oral iron using the CKD-EPI formula $(p=0.012)$ which was confirmed on multivariate analysis. There was no difference between groups in the rate of progression to dialysis and no evidence of increased renal adverse events in either FCM treatment group.

Clinical studies measuring the short- or long-term effect of IV iron complexes on renal function versus controls are relatively scarce. Van Wyck et al. randomized 188 patients with ND-CKD to a total dose of $1000 \mathrm{mg}$ iron as iron sucrose (infused over 3.5-4 h) or oral iron sulfate [10]. At the end of the 6-week study, there was a mean decrease in eGFR in both treatment arms, but the decrease was smaller in the iron sucrose $\operatorname{arm}\left(-1.45 \mathrm{~mL} / \mathrm{min} / 1.73 \mathrm{~m}^{2}\right.$ versus $-4.40 \mathrm{~mL} / \mathrm{min} /$ $1.73 \mathrm{~m}^{2}$ in the oral iron arm; $\left.p=0.01\right)$. McMahon et al. undertook a randomized trial of iron sucrose (100$200 \mathrm{mg}$ every two months) or oral iron sulfate for 12 months in patients with ND-CKD who were nonanemic $(\mathrm{Hb} \geq 11 \mathrm{~g} / \mathrm{dL})$ and iron replete (ferritin $>300 \mu \mathrm{g} /$ $\mathrm{L}$ and TSAT $>25 \%$ ) at baseline, and has described a similar change in eGFR in both treatment groups over the study period [29]. This similarity was observed despite elevated iron indices in the IV iron group at month 12 (mean ferritin $363 \mu \mathrm{g} / \mathrm{L}$ versus $125 \mu \mathrm{g} / \mathrm{L}$ in the oral iron group; TSAT $30 \%$ versus $21 \%$ ). However, the study analyzed only 85 patients, such that a relatively small effect on renal function may have remained undetected, and 
the study protocol specified only modest doses of iron supplementation in both the IV and oral iron groups (the actual amount administered was not specified). Lastly, a recent randomized trial of IV iron sucrose versus oral iron showed no change in measured GFR over 2 years' follow-up between the two arms of the study [24]. Other randomized trials comparing IV iron versus oral iron have not reported renal function, but there was no evidence of a higher rate of renal adverse events in the IV iron groups versus patients receiving oral iron therapy $[7-9,11]$.

Regarding a possible effect of IV iron on proteinuria, in a blinded, randomized, placebo-controlled cross-over study of eight patients with ND-CKD, Leehey et al. assessed the effect of a single dose of ferric gluconate at a dose of $125 \mathrm{mg}$ iron infused over one hour, or $250 \mathrm{mg}$ iron over two hours [21]. They observed no evidence of acute renal injury, as assessed by albuminuria, proteinuria or enzymuria, although plasma levels of the oxidative stress marker malondialdehyde (MDA) increased with both doses. Another randomized trial, by Agarwal and colleagues, administered a single dose of $100 \mathrm{mg}$ iron sucrose to 20 subjects with CKD stage 3 or 4 , and also found an increase in MDA versus controls, accompanied by transient proteinuria and enzymuria which resolved within $24 \mathrm{~h}$ [22]. Similar analyses have been performed in repeated dose studies. In a multicenter, randomized trial, 62 patients with ND-CKD and iron deficiency anemia received a weekly dose of either iron sucrose or ferric gluconate $(100 \mathrm{mg})$ for 5 weeks [19]. Basal levels of proteinuria were similar, but increased post-dosing, with a greater increase with iron sucrose than ferric gluconate [19]. This was consistent with results from an earlier single-dose study from the same group which showed that a single dose of iron sucrose $(100 \mathrm{mg})$ provoked a significantly higher urinary protein to creatinine ratio than ferric gluconate [20]. The difference between iron sucrose and ferric gluconate is somewhat unexpected, since the latter is considered to be less stable. Other authors have reported that rapid infusion (5 min) of iron dextran or iron sucrose results in generation of reactive oxygen species [15], whereas a study of 20 iron-replete dialysis patients found that slow infusion (60 $\mathrm{min}$ ) of these preparations did not affect biomarkers of oxidative stress or inflammation [30] (neither study measured renal function). Finally, in the prospective REVOKE trial [24], which was designed to detect renal toxicity of IV iron, proteinuria was similar in the IV iron sucrose and oral iron arms.

In the current study, FCM-treated patients received an initial single dose of up to $1000 \mathrm{mg}$ iron in the high ferritin group, or $200 \mathrm{mg}$ in the low ferritin group (each infused over $15 \mathrm{~min}$ ), with mean total doses of $\sim 2800 \mathrm{mg}$ iron and $\sim 1200 \mathrm{mg}$ iron, respectively, among patients with eGFR data available at baseline and month 12 . A post hoc analysis indicated that within this range, there was no association between quartiles of FCM dose and the change in eGFR during the 12 months after the start of FCM therapy. Moreover, neither absolute levels of ferritin (a marker for iron stores) nor TSAT (a marker for iron availability) at month 12 , nor the change in ferritin or TSAT during the study, showed an association with change in eGFR. Thus, the significant increase in ferritin levels achieved in the cohort of patients randomized to high ferritin FCM was not associated with a change in renal function.

\section{Conclusions}

The main limitation of these findings is the 1-year duration of the FIND-CKD trial which, while longer than most previous comparative studies of IV versus oral iron [7-11, 24], may not be adequate to detect a long-term effect on renal function. Within the full study cohort, we restricted the analysis to the patients who remained on the randomized study drug for the full 12-month study; any patient in whom another anemia therapy was introduced or who discontinued the study prematurely was excluded. While this reduced the population size, we believe that this was the most rigorous analytical approach. No patient discontinued the study due to decreasing renal function so bias due to selective discontinuation can be ruled out. Moreover, baseline and month 12 values for eGFR (and the extent of change from baseline to month 12) were similar in each treatment group to those seen in the full ITT population [25]. A post hoc repeated measured modeling calculation showed that the population analyzed here $(n=353)$ had a 15 and $18 \%$ power, respectively, to detect a difference of $1.0 \mathrm{ml} / \mathrm{min} /$ $1.73 \mathrm{~m}^{2}$ in the change in eGFR between the high and low ferritin FCM groups, and between the high ferritin FCM and oral iron groups (40 and $49 \%$, respectively, to detect a difference of $2 \mathrm{~mL} / \mathrm{min} / 1.73 \mathrm{~m}^{2}$ ). The study used eGFR as the indicator of renal function rather than a method to measure GFR. Furthermore, GFR estimates were based on locally determined serum creatinine values, so that variability between methods at different sites cannot be excluded. It is unlikely, however, that such variations would have obscured differences between treatment groups, since each patient served as their own control at baseline using the same assay. Another limitation is that urinary protein excretion and biomarkers of renal tubular toxicity were not recorded. Also, patients previously showing a rapidly progressive loss of renal function at screening were excluded from the study. Indeed, it is remarkable that the annual loss of eGFR was no more than $1.6 \mathrm{~mL} / \mathrm{min} / 1.73^{2}$ in any group. Other eligibility criteria for the study may have contributed to this stability, notably exclusion of patients with previous 
eGFR loss $>12 \mathrm{~mL} / \mathrm{min} / 1.73 \mathrm{~m}^{2} /$ year but also, for example, those with poorly controlled hypertension. Moreover, approximately three-quarters of patients were receiving an ACE inhibitor or an angiotensin II receptor antagonist. Lastly, in terms of the study design, the absence of a placebo arm precludes a comparison of renal function using IV iron versus no treatment and would have contributed to understanding if the observed stability of renal function was partly a trial effect.

In conclusion, results from this study indicate a lack of renal toxicity of IV iron therapy in patients with relatively stable renal function. It is important to note that these results do not necessarily apply to other IV iron preparations, due to varying molecular structures and physiochemical properties, or to patients with other characteristics (for example those receiving dialysis). Assessment of longer-term effects of IV iron, however, is required.

\section{Appendix 1}

\section{The FIND-CKD Investigators}

Australia: Simon D Roger (Gosford), Alastair Gilles (Newcastle), Randall Faull (Adelaide), Nigel D Toussaint (Parkville), Lawrence McMahon (Box Hill), Michael Suranyi (Liverpool), David Mudge (Brisbane), Brian Hutchison (Perth), Ashley Irish (Perth), Peter Kerr (Clayton), Hemant Kulkarni (Perth and Armadale), Grahame Elder (Westmead), Margaret Jardine (Concord); Austria: Karl Lhotta (Feldkirch), Gert Mayer (Innsbruck); Belgium: Raymond Vanholder (Gent), Bart Dirk Maes (Roeselare), Pieter Evenepoel (Leuven), Frédéric Debelle (Baudour), Michel Jadoul (Brussels), Max Dratwa (Brussels); Czech Republic: Igor Macel (Zdar nad Sazavou), Milan Dunaj (Litomysl), Milan Kvapil (Praha), Petr Bucek (Frydek-Mistek), Jitka Rehorova (Brno), Ales Hruby (Slavkov u Brna), Václava Honová (Pizen), Lada Malanova (Pizen), Martin Lucak (Prague), Dalibor Lecian (Praha), Martin Jirovec (Marianske Lazne), Jiri Vlasak (Sokolov), Ivan Rychlik (Sokolov), Stanislav Surel (Brno); Denmark: Anne-Lise Kamper (Kobehavn), Ove Ostergaard (Roskilde), Gudrun K Steffensen (Frederica); France: Leila Chenine (Montpellier), Gabrial Choukroun (Amiens), Philippe Zaoui (Grenoble); Germany: Christoph Wanner (Würzburg), Wolfgang Backs (Hamburg), Uwe Kraatz (Demmin), Frank Dellanna (Düsseldorf), Klaus Busch (Dortmund), Tobias Marsen (Köln), Wolfgang Seeger (Berlin), Rainer Woitas (Bonn), Nicholas Obermueller (Frankfurt/Main), Thomas Haak (Bad Mergentheim), Stephan Lueders (Cloppenburg), Frank Pistrosch (Hoyerswerda), Eckhard Mueller (Benkastel-Kues), Peter R Mertens (Magdeburg), Werner Sutermer (Würzburg), Scott-Oliver Grebe (Wuppertal), Syrus Hafezi-Rachti (Mannheim-Käfertal), Silke Roeser (Eberswalde); Greece: Dimitrios Tsakiris (Thessaloniki), Dimitrios Memmos (Thessanloniki), Demetrios Vlachakos
(Chaidari, Athens), Vassilis Vargemezis (Dragana, Alexandroupolis), Ioannis Stefanidis (Mezourlo, Larissa), Christos Syrganis (Volos), Polichronis Alivanis (Rhodes), Ioannis Papadakis (Athens), Nickolaos Papagalanis (Athens), Aimilios Andrikos (Joannina), Dimitrios Goumenos (Rios Patras), Kostas Siamopoulos (Ioannina), Charikelia Gouva (Arta), Gabriel Papadakis (Peireus), Ioannis Boletis (Athens), Myrsini Tsimnadi-Spanoudaki (Vestos), Dimitrios Stamatiades (Serres), Kyriaki Stamatelou (Athens), Spyridon Moutafis (Athens); Italy: Francesco Locatelli (Lecco), Antonio Santoro (Bologna), Francesco Quarello (Torino), Giuseppe Remuzzi (Bergamo), Salvatore Coppola (Piedmonte Matese), Rosella Ferraro Mortellaro (Dan Daniele del Friuli), Andrea Icardi (Arenzano), Giacomo Colussi (Milan), Franco Della Grotta (Anzio), Luigi Lombardi (Ctanzaro), Maurizio Gallieni (Milano), Giuseppe Villa (Pavia), Giuseppe Grandaliano (Foggia); The Netherlands: Carlo Gaillard (Amersfoort and Amsterdam), Sebastiaan Huisman (Delft), Jos Barendregt (Apeldoorn), Peter JH Smak Gregoor (Dordrecht); Norway: Cecilia Oien (Trondheim); Poland: Boleslaw Rutkowski (Gdansk), Robert Malecki (Warszawa), Michal Nowicki (Lodz), Przemyslaw Rutkowski (Starogard Gdanski), Kryzsztof Marczewski (Zamosc), Michal Mysliwiec (Bialystok), Antoni Sydor (Tarnow), Jacek Rysz (Lodz), Andrzej Rydzewski (Warszawa), Marian Klinger (Wroclaw), Rafal Wnuk (Dabrowa Gornicza), Piotr Kozminski (Mlawa), Anna Nocon (Wroclaw), Kazimierz Ciechanowski (Szczecin); Portugal: Pedro Correia (Amadora), Fernando Neves (Lisboa), José Barata (Carnaxide); Romania: Gabriel Mircescu (Bucuresti), Mihai Voiculescu (Bucuresti), Gheorghe Gluhovschi (Timisoara), Eugen Mota (Craiova); Spain: Angel Luís Martín De Francisco (Santander), Alberto Torre (Madrid), Alba Herreros (Barcelona), José Luño (Madrid), E Gruss (Alcorcón), Judith Martins (Getafe [Madrid]), Marti Vallés (Girona), Julio Pascual (Barcelona); Sweden: Peter Bárány (Stockholm); Switzerland: Andreas H Bock (Aarau), Patrice M Ambuehl (Zürich); Turkey: Sehsuvar Erturk (Ankara), Mustafa Arici (Ankara), Saime Paydas (Adnana), Zeki Soypacaci (Izmir), Taner Camsari (Izmir), Sedat Ustundag (Edirne); United Kingdom: Iain C Macdougall (London), Mark E Thomas (Birmingham), Richard J D'Souza (Exeter), Jo E Taylor (Dorchester), Nicholas R Pritchard (Cambridge), Robin Jeffery (Bradford), Stephen G Riley (Cardiff), Deepak Bhatnagar (Oldham), Sunil Bhandari (Hull), David Reaich (Middlesborough), Paul E Stevens (Canterbury), Mohsen El Kossi (Doncaster), Simon Roe (Nottingham), Brian Camilleri (Ipswich), Aimun Ahmed (Preston), Arif Khwaja (Sheffield), Barbara Thompson (Stevenage), Debasish Banerjee (London), Johann Nicholas (Wolverhampton), Alistair Hutchison (Manchester), Richard Borrows (Birmingham). 


\section{Appendix 2}

Table 3 FIND-CKD trial: Ethics Committee approvals

\begin{tabular}{|c|c|c|}
\hline Country & $\begin{array}{l}\text { Site } \\
\mathrm{Nr}\end{array}$ & Ethic Committee \\
\hline Australia & 0101 & $\begin{array}{l}\text { Bellberry HREC } 229 \text { Greenhill Road Dulwich } \\
\text { SA } 5065\end{array}$ \\
\hline Australia & 0102 & $\begin{array}{l}\text { Bellberry HREC } 229 \text { Greenhill Road Dulwich } \\
\text { SA } 5065\end{array}$ \\
\hline Australia & 0103 & $\begin{array}{l}\text { Hunter Area Research Ethics Committee John } \\
\text { Hunter Hospital Lookout Road } \\
\text { New Lambton Heights NSW } 2305\end{array}$ \\
\hline Australia & 0104 & $\begin{array}{l}\text { Research Ethics Committee Royal Adelaide } \\
\text { Hospital North Terrace } \\
\text { Adelaide SA } 5000\end{array}$ \\
\hline Australia & 0105 & $\begin{array}{l}\text { Human Research Ethics Committee Royal } \\
\text { Melbourne Hospital Parkville, Victoria } 3050\end{array}$ \\
\hline Australia & 0106 & $\begin{array}{l}\text { Eastern Health HREC Level 2, } 5 \text { Arnold Street } \\
\text { Box Hill, Victoria } 3 f 28\end{array}$ \\
\hline Australia & 0106 & $\begin{array}{l}\text { Eastern Health HREC Level 2, } 5 \text { Arnold Street } \\
\text { Box Hill, Victoria } 3 f 29\end{array}$ \\
\hline Australia & 0107 & $\begin{array}{l}\text { Hunter Area Research Ethics Committee John } \\
\text { Hunter Hospital Lookout Road } \\
\text { New Lambton Heights NSW } 2305\end{array}$ \\
\hline Australia & 0108 & $\begin{array}{l}\text { PAH Human Research Ethics Committee Tafe 3, } \\
\text { Level 2, Bldg } 35 \\
\text { Princess Alexandra Hospital Ispswich Road } \\
\text { Woolloongabba, QLD } 4 \mathrm{fO} 2\end{array}$ \\
\hline
\end{tabular}
Australia 9 Ballarat Health Services and St. John of God Health Care Ethics Committee Base Hospital Drummond Street North PO Box 577 Ballarat 3353

Australia

0110 Hunter Area Research Ethics Committee John Hunter Hospital Lookout Road New Lambton Heights NSW 2305

Australia

0111 Hunter Area Research Ethics Committee John Hunter Hospital Lookout Road New Lambton Heights NSW 2306

Australia 0111 Royal Brisbane and Women's Hospital HREC University of Queensland, Centre for Clinical Research, Level 4, RBWH HERSTON, QUEENSLAND AUSTRALIA 4029

Australia

0112 Sir Charles Gairdner HREC Level 2, A block Hospital Avenue Nedlands, WA 6009

Australia 0113 Royal Perth Hospital HREC Colonial House Wellington Street, WA 6000

Australia 0114 Southern Health HREC 246 Clayton Road Clayton, Victoria 3168

Australia 0115 Sir Charles Gairdner HREC Level 2, A block Hospital Avenue Nedlands, WA 6009

Australia 0117 Cairns Base Hospital Ethics Committee PO Box 902 Cairns, QLD 4870

Australia 0118 Hunter Area Research Ethics Committee John Hunter Hospital Lookout Road New Lambton Heights NSW 2305

Australia 0119 Hunter Area Research Ethics Committee John Hunter Hospital Lookout Road New Lambton Heights NSW 2305
Table 3 FIND-CKD trial: Ethics Committee approvals (Continued)

\begin{tabular}{lll}
\hline Australia & 0120 & $\begin{array}{l}\text { Sir Charles Gairdner HREC Level 2, A block } \\
\text { Hospital Avenue Nedlands, WA 6009 }\end{array}$ \\
Austria & 0202 & $\begin{array}{l}\text { Ethikkommission der Stadt Wien Town Thomas- } \\
\text { Klestil-Platz 8/2 A-1030 Wien, Osterreich }\end{array}$ \\
Austria & 0203 & $\begin{array}{l}\text { Ethikkommission der Stadt Wien Town Thomas- } \\
\text { Klestil-Platz 8/2 A-1030 Wien, Osterreich }\end{array}$ \\
Austria & 0204 & $\begin{array}{l}\text { Ethikkommission des Landes Vorarlberg } \\
\text { Rathausstrassed 15 } \\
\text { A-6900 Bregenz } \\
\text { Osterreich }\end{array}$ \\
& &
\end{tabular}

Austria $\quad 0205$ Ethikkommission Krankenhaus der Elisabethinen Linz GmbH Fadingerstrasse 1 A-4 Linz Osterreich

Austria 0206 Ethikkommission der Medizinischen Universitat Innsbruck Innrain 43 A-6020 Innsbruck Osterreich

Austria

0207 EK des Landes Oberosterreich Landesnervenklinik Wagner-Jauregg Strasse Wagner-Jauregg Weg 15 A-4020 Linz Osterreich

Belgium

0301 Secretariaat Ethische Commissie UZ Gent Attn. Prof. Dr Matthys De Pintelaan 185 9000 Gent

Belgium

0302 H.-Hartziekenhuis Roeselare-Menen vzw Attn. Dr. Ludo Marcelis WILGENSTRAAT 2 8800 ROESELARE

Belgium 0303 Dr Van Vlem

Onze-Lieve-Vrouwziekenhuis Attn. Greet de Geest Moorselbaan 1649300 Aalst

Belgium 0304 Commissie Medische Ethiek van Universitaire Ziekenhuizen K.U.Leuven Attn. Prof. Walter Van den Bogaert

Campus Gasthuisberg E330 Herestraat 49 B-3000 Leuven

Belgium $0305 \quad$ Kristien Schoenmakers gang beheer en directie ZOL Campus St Jan Schiepse bos 63600 Genk

Belgium 0306 Hopitaux IRIS Sud-site Joseph Bracops Rue Dr Huet 79 Brussels 1070

Belgium 0307 Comité d'Ethique du Epicura Ath-Baudour Attn. Dr Frederic Debelle 136 rue Louis Caty 7331 Baudour

Belgium 0308 Commission d'Ethique Biomédicale HospitaloFacultaire Attn. Pr Jean-Marie Maloteaux Cliniques Universitaires Saint-Luc Avenue Hippocrate 55/14 B-1200 Bruxelles

Belgium

0309 Comite d'Ethique Hospitalo-Facultaire Universitaire de Liege Centre Hospitalier Universitaire du Sart Tilman, B35 4000 Sart Tilman par Liege 1

Belgium 0311 Centre Hospitalier Universitaire Brugman Attn. Valsamis Joseph

Place A. Van Gehuchten, 41020 Bruxelles -2

Belgium 0312 Comite d'Ethique Clinique Universitaire de Bruxelles Hopital Erasme Route de Lennik 8081070 Bruxelles - 7

Czech Republic

0401 Etická komise IKEM a FN Thomayerovy s poliklinikou Vídeňská 80014059 Praha 4

Czech Republic
0402 Etická komise pro multicentrická hodnocení Fakultní nemocnice v Motole V úvalu 84, 15006 Praha 5 
Table 3 FIND-CKD trial: Ethics Committee approvals (Continued)

\begin{tabular}{|c|c|c|}
\hline $\begin{array}{l}\text { Czech } \\
\text { Republic }\end{array}$ & 0403 & $\begin{array}{l}\text { Etická komise Litomyšlská nemocnice } \\
\text { a.s. J. E. Purkyně } 65257014 \text { Litomyšl }\end{array}$ \\
\hline $\begin{array}{l}\text { Czech } \\
\text { Republic }\end{array}$ & 0404 & $\begin{array}{l}\text { Etická komise Nemocnice Jihlava } \\
\text { Vrchlického } 5958601 \text { Jihlava }\end{array}$ \\
\hline $\begin{array}{l}\text { Czech } \\
\text { Republic }\end{array}$ & 0405 & $\begin{array}{l}\text { Etická komise pro multicentrická hodnocení } \\
\text { Fakultní nemocnice v Motole V Úvalu } \\
\text { 84, } 15006 \text { Praha } 5\end{array}$ \\
\hline $\begin{array}{l}\text { Czech } \\
\text { Republic }\end{array}$ & 0406 & $\begin{array}{l}\text { Etická komise } \\
\text { Krajská nemocnice T. Bati a.s. Zlín Havlíčkovo } \\
\text { nábřeží } 60076275 \text { Zlín }\end{array}$ \\
\hline $\begin{array}{l}\text { Czech } \\
\text { Republic }\end{array}$ & 0407 & $\begin{array}{l}\text { Etická komise Fakultní nemocnice Hradec } \\
\text { Králové Sokolská } 58150005 \text { Hradec Králové }\end{array}$ \\
\hline $\begin{array}{l}\text { Czech } \\
\text { Republic }\end{array}$ & 0408 & $\begin{array}{l}\text { Etická Komise Nemocnice Písek, a.s. Karla } \\
\text { Čapka } 58939723 \text { Písek }\end{array}$ \\
\hline $\begin{array}{l}\text { Czech } \\
\text { Republic }\end{array}$ & 0409 & $\begin{array}{l}\text { Etická komise Nemocnice Tábor, a.s. Kpt. } \\
\text { Jaroše } 200039003 \text { Tábor }\end{array}$ \\
\hline $\begin{array}{l}\text { Czech } \\
\text { Republic }\end{array}$ & 0410 & $\begin{array}{l}\text { Etická komise } \\
\text { Nemocnice ve Frýdku-Místku, p.o. El. } \\
\text { Krásnohorské } 32173818 \text { Frýdek-Místek }\end{array}$ \\
\hline $\begin{array}{l}\text { Czech } \\
\text { Republic }\end{array}$ & 0411 & $\begin{array}{l}\text { Etická komise } \\
\text { FN Brno Bohunice Jihlavská } 2062500 \text { Brno }\end{array}$ \\
\hline $\begin{array}{l}\text { Czech } \\
\text { Republic }\end{array}$ & 0412 & $\begin{array}{l}\text { Etická komise B. Braun Avitum Bulovka } \\
\text { Budínova } 6718102 \text { Praha } 8\end{array}$ \\
\hline $\begin{array}{l}\text { Czech } \\
\text { Republic }\end{array}$ & 0413 & $\begin{array}{l}\text { Etická komise B. Braun Avitum Bulovka } \\
\text { Budínova } 6718102 \text { Praha } 8\end{array}$ \\
\hline $\begin{array}{l}\text { Czech } \\
\text { Republic }\end{array}$ & 0414 & $\begin{array}{l}\text { Etická komise Nemocnice s poliklinikou } \\
\text { v Novém Jičíně, p.o. } \\
\text { K Nemocnici } 775 / 7674101 \text { Nový Jičín }\end{array}$ \\
\hline $\begin{array}{l}\text { Czech } \\
\text { Republic }\end{array}$ & 0415 & $\begin{array}{l}\text { Etická komise B. Braun Avitum Bulovka } \\
\text { Budínova } 6718102 \text { Praha } 8\end{array}$ \\
\hline $\begin{array}{l}\text { Czech } \\
\text { Republic }\end{array}$ & 0416 & $\begin{array}{l}\text { Etická komise Nemocnice Znojmo MUDr. } \\
\text { Jana Janského } 1166902 \text { Znojmo }\end{array}$ \\
\hline $\begin{array}{l}\text { Czech } \\
\text { Republic }\end{array}$ & 0417 & $\begin{array}{l}\text { Etická komise B. Braun Avitum Bulovka } \\
\text { Budínova } 6718102 \text { Praha } 8\end{array}$ \\
\hline $\begin{array}{l}\text { Czech } \\
\text { Republic }\end{array}$ & 0418 & $\begin{array}{l}\text { Etická komise společnosti Fresenius Medical } \\
\text { Care - DS, s.r.o. } \\
\text { Lužná } 591 \\
16005 \text { Praha } 6\end{array}$ \\
\hline $\begin{array}{l}\text { Czech } \\
\text { Republic }\end{array}$ & 0419 & $\begin{array}{l}\text { Etická komise pro multicentrická hodnocení } \\
\text { Fakultní nemocnice v Motole V Úvalu } 84 \\
15006 \text { Praha } 5\end{array}$ \\
\hline $\begin{array}{l}\text { Czech } \\
\text { Republic }\end{array}$ & 0420 & $\begin{array}{l}\text { Etická komise společnosti Fresenius Medical } \\
\text { Care - DS, s.r.o. } \\
\text { Lužná } 591 \\
16005 \text { Praha } 6\end{array}$ \\
\hline $\begin{array}{l}\text { Czech } \\
\text { Republic }\end{array}$ & 0421 & $\begin{array}{l}\text { Etická komise společnosti Fresenius Medical } \\
\text { Care - DS, s.r.o. } \\
\text { Lužná } 591 \\
16005 \text { Praha } 6\end{array}$ \\
\hline $\begin{array}{l}\text { Czech } \\
\text { Republic }\end{array}$ & 0422 & $\begin{array}{l}\text { Etická komise společnosti Fresenius Medical } \\
\text { Care - DS, s.r.o. } \\
\text { Lužná } 591 \\
16005 \text { Praha } 6\end{array}$ \\
\hline $\begin{array}{l}\text { Czech } \\
\text { Republic }\end{array}$ & 0423 & $\begin{array}{l}\text { Etická komise společnosti Fresenius Medical } \\
\text { Care - DS, s.r.o. } \\
\text { Lužná } 591 \\
16005 \text { Praha } 6\end{array}$ \\
\hline
\end{tabular}

Table 3 FIND-CKD trial: Ethics Committee approvals (Continued)

\begin{tabular}{|c|c|c|}
\hline $\begin{array}{l}\text { Czech } \\
\text { Republic }\end{array}$ & 0424 & $\begin{array}{l}\text { Etická komise pro multicentrická hodnocen } \\
\text { Fakultní nemocnice v Motole V Úvalu 84, } \\
15006 \text { Praha } 5\end{array}$ \\
\hline Denmark & 0501 & $\begin{array}{l}\text { De Videnskabsetiske Komiteer for Region } \\
\text { Hovedstaden } \\
\text { Regionsgarden } \\
\text { Kongesn Vaenge } \\
\text { CK-3400 Hillerod }\end{array}$ \\
\hline Denmark & 0502 & $\begin{array}{l}\text { De Videnskabsetiske Komiteer for Region } \\
\text { Hovedstaden } \\
\text { Regionsgarden } \\
\text { Kongesn Vaenge } \\
\text { CK-3400 Hillerod }\end{array}$ \\
\hline
\end{tabular}

Denmark 0503 De Videnskabsetiske Komiteer for Region Hovedstaden Regionsgården Kongens Vænge 2 DK-3400 Hillerød

Denmark 0504 De Videnskabsetiske Komiteer for Region Hovedstaden Regionsgarden Kongesn Vaenge CK-3400 Hillerod

France

0601 CPP Sud-Méditerranée IV Dr Alain DUBOIS Hopital Saint Eloi Rue Bertin Sand 34295 Montpellier Cedex 5

France

0601 CPP Sud-Méditerranée IV

Dr Alain DUBOIS

Hopital Saint Eloi

Rue Bertin Sand

34295 Montpellier

Cedex 5

France

0602 CPP Sud-Méditerranée IV Dr Alain DUBOIS Hôpital Saint Eloi Rue Bertin Sans 34295 Montpellier Cedex 5

France

0603 CPP Sud-Méditerranée IV Dr Alain DUBOIS Hôpital Saint Eloi Rue Bertin Sans 34295 Montpellier Cedex 5

France

0604 CPP Sud-Méditerranée IV Dr Alain DUBOIS Hôpital Saint Eloi Rue Bertin Sans 34295 Montpellier Cedex 5

France

0605 CPP Sud-Méditerranée IV Dr Alain DUBOIS Hôpital Saint Eloi Rue Bertin Sans 34295 Montpellier Cedex 5

France $\quad 0606$ CPP Sud-Méditerranée IV Dr Alain DUBOIS Hôpital Saint Eloi Rue Bertin Sans 34295 Montpellier Cedex 5

France $\quad 0607$ CPP Sud-Méditerranée IV Dr Alain DUBOIS Hôpital Saint Eloi Rue Bertin Sans 34295 Montpellier Cedex 5

France

0608 CPP Sud-Méditerranée IV Dr Alain DUBOIS Hôpital Saint Eloi Rue Bertin Sans 34295 Montpellier Cedex 5

France

0609 CPP Sud-Méditerranée IV Dr Alain DUBOIS Hôpital Saint Eloi Rue Bertin Sans 34295 Montpellier Cedex 5

France

0610 CPP Sud-Méditerranée IV Dr Alain DUBOIS Hôpital Saint Eloi Rue Bertin Sans 34295 Montpellier Cedex 5 
Table 3 FIND-CKD trial: Ethics Committee approvals (Continued)

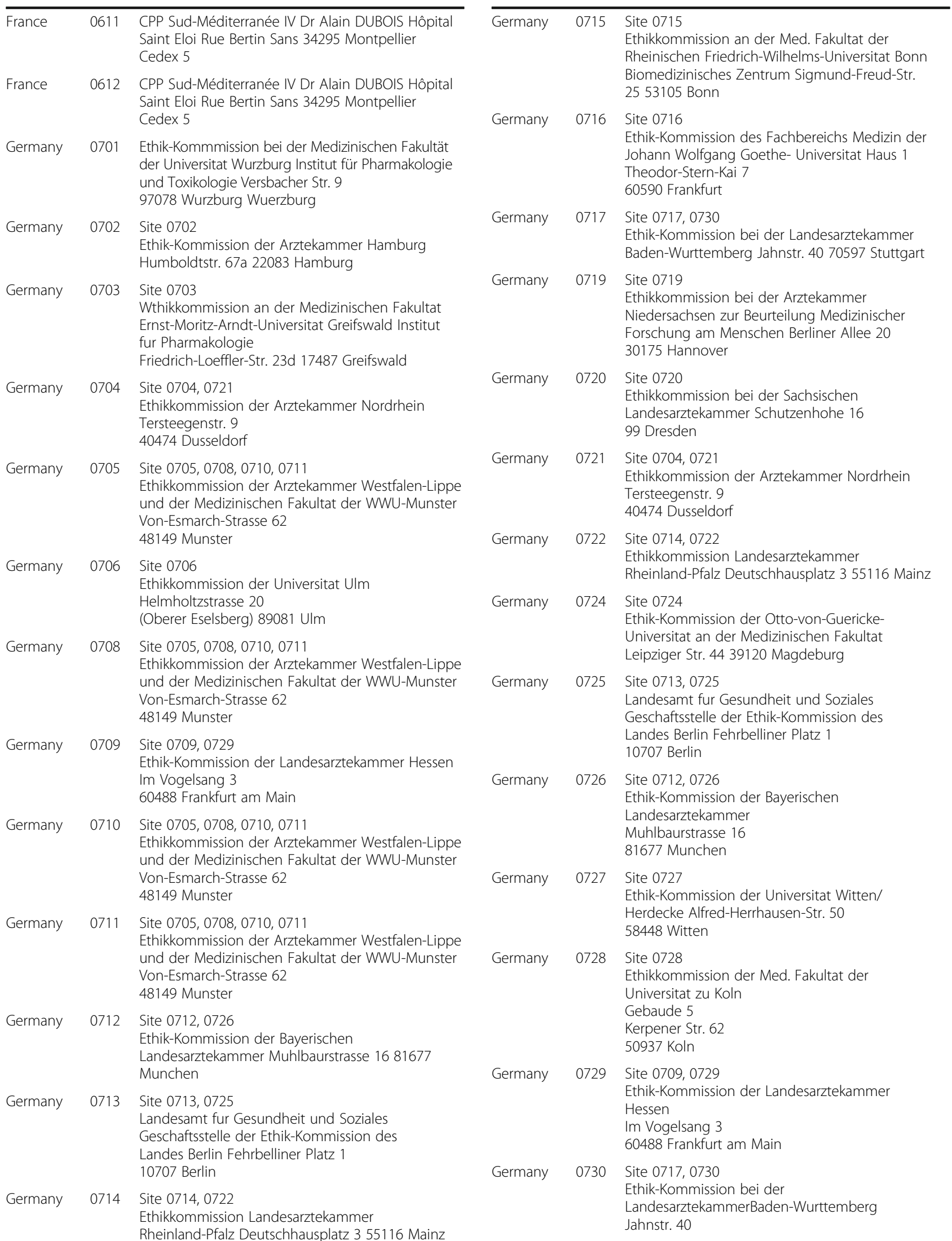

Table 3 FIND-CKD trial: Ethics Committee approvals (Continued) 
Table 3 FIND-CKD trial: Ethics Committee approvals (Continued)

\begin{tabular}{|c|c|c|}
\hline & & 70597 Stuttgart \\
\hline Germany & 0731 & $\begin{array}{l}\text { Site } 0731 \\
\text { Ethik-Kommission der Landesarztekammer } \\
\text { Brandenburg } \\
\text { Dreifertstrasse } 12 \\
\text { 03044 Cottbus }\end{array}$ \\
\hline Greece & 0801 & $\begin{array}{l}\text { Ethical Committee } \\
\text { General University Hospital of Thessaloniki } \\
\text { "Papgeorgiou" Thessaloniki Ring Road, Nea } \\
\text { Efkarpia Thessaloniki, } 56429\end{array}$ \\
\hline Greece & 0802 & $\begin{array}{l}\text { General Hospital of Thessaloniki "Ippokrateion" } \\
49 \text { Konstantinoupoleos st. Thessaloniki, } 56442\end{array}$ \\
\hline Greece & 0803 & $\begin{array}{l}\text { ATTIKON General University Hospital of Athens } \\
1 \text { Rimini Str. } \\
\text { Chaidari, Athens, } 12462\end{array}$ \\
\hline Greece & 0804 & $\begin{array}{l}\text { General University Hospital of Alexandroupolis } \\
\text { Dragana Alexandroupolis, } 68100\end{array}$ \\
\hline Greece & 0805 & $\begin{array}{l}\text { Ethical Commitee } \\
\text { General University Hospital of Larissa Mezourlo } \\
\text { Larissa, } 41110\end{array}$ \\
\hline Greece & 0806 & $\begin{array}{l}\text { Ethics Committee } \\
\text { Achillopoulio General Prefecture Hospital of } \\
\text { Volos } 134 \text { Polyeri street } \\
\text { Volos, } 38222\end{array}$ \\
\hline Greece & 0807 & $\begin{array}{l}\text { Ethical Commitee } \\
\text { General Hospital of Rhodes Aghioi Aphostoloi } \\
\text { Rhodes, } 85100\end{array}$ \\
\hline Greece & 0808 & $\begin{array}{l}\text { Ethical Commitee } \\
\text { IPPOKRATEION General Hospital of Athens } 114 \\
\text { Vas. Sofias Ave Athens, } 11526\end{array}$ \\
\hline Greece & 0809 & $\begin{array}{l}\text { Ethical Commitee } \\
\text { General Hospital of Athens, KORGALENEIO- } \\
\text { BENAKEIO Athenasaki Str. } 1 \\
\text { Athens, } 11526\end{array}$ \\
\hline Greece & 0810 & $\begin{array}{l}\text { Ethical Commitee } \\
\text { General Prefecture Hospital of loannina, } \\
\text { XATZIKOSTA Avv. Makrigianni } 1 \\
\text { loannina, } 45550\end{array}$ \\
\hline Greece & 0811 & $\begin{array}{l}\text { Ethical Commitee } \\
\text { General University Hospital of Patras Rio-Patras } \\
\text { Street Rios Patras, } 16500\end{array}$ \\
\hline Greece & 0812 & $\begin{array}{l}\text { Ethical Commitee } \\
\text { General University Hospital of loannina Stavros } \\
\text { Niarchos Avenue loannina, } 45550\end{array}$ \\
\hline Greece & 0813 & $\begin{array}{l}\text { Ethical Commitee General Hospital of Arta } \\
\text { A. Zara Str } 4 \text { Arta, } 47100\end{array}$ \\
\hline Greece & 0815 & $\begin{array}{l}\text { Ethical Commitee } \\
\text { General Hospital of Peireus "Tzaneio" Zanni \& } \\
\text { Afendouli Peireus, } 18536\end{array}$ \\
\hline Greece & 0817 & $\begin{array}{l}\text { Ethical Commitee } \\
\text { General Prefecture Hospital of Argos } 191 \\
\text { Korinthou Str. } \\
\text { Argos, } 21200\end{array}$ \\
\hline Greece & 0818 & $\begin{array}{l}\text { Ethical Commitee } \\
\text { LAIKO General Hospital of Athens } 17 \text { Aghiou } \\
\text { Thomas Str. } \\
\text { Athens, } 11527\end{array}$ \\
\hline
\end{tabular}

Table 3 FIND-CKD trial: Ethics Committee approvals (Continued)

\begin{tabular}{|c|c|c|}
\hline reece & 0819 & $\begin{array}{l}\text { Ethical Commitee } \\
\text { General Hospital of Mytilene "Vostanio" } 48 \text { E. } \\
\text { Vostani Str. } \\
\text { Vestos, } 81100\end{array}$ \\
\hline ece & 0820 & $\begin{array}{l}\text { Ethical Commitee General Hospital of Serres 2nd } \\
\text { k of Serres-Drama National Road Serres, } 62100\end{array}$ \\
\hline ece & 0821 & $\begin{array}{l}\text { Ethical Commitee } \\
\text { KYANOUS STAVROS General Hospital of Athens } \\
102 \text {, Vas Sofias Ave Athens, } 11528\end{array}$ \\
\hline ece & 0822 & $\begin{array}{l}\text { Ethical Commitee } \\
\text { IASO General Hospital of Athens Cholargos } \\
\text { Athens, } 11526\end{array}$ \\
\hline ece & 0823 & $\begin{array}{l}\text { Ethical Commitee } \\
\text { General Hospital of Athens "Henry Dunant" } 107 \\
\text { Messogheion Ave Athens, } 11526\end{array}$ \\
\hline & 1001 & $\begin{array}{l}\text { Comitato Etico } \\
\text { Dell'Azienda Ospedaliera di Lecco Via Dell'Eremo } \\
\text { 9/11 Lecco, } 23900\end{array}$ \\
\hline & 1002 & $\begin{array}{l}\text { Comitato Etico Locale per la Sperimentazione } \\
\text { Clinical Della AUSL } 12 \text { di Viareggio Via Aurelia } 335 \\
55045 \text { Lido di Cà Maiore (LC) }\end{array}$ \\
\hline ly & 1003 & $\begin{array}{l}\text { Comitato Etico Dell'Azeinda Ospedaliera } \\
\text { Universitaria Della Seconda Univestità degli } \\
\text { Studi di Napoli Via Costatinopoli, } 104 \\
80138 \text { Napoli }\end{array}$ \\
\hline aly & 1004 & $\begin{array}{l}\text { Comitato Etico Indipendente dell'Azienda } \\
\text { ospedaliero-Univesitaria Policlinico S. Orsola } \\
\text { Via Albertoni } 15 \\
40138 \text { Bologna }\end{array}$ \\
\hline aly & 1005 & $\begin{array}{l}\text { Comitato Etico Della ASL TO/2 di Torino Corso } \\
\text { Svizzera } 185 \text { bis } 10149 \text { Torino }\end{array}$ \\
\hline$y$ & 1007 & $\begin{array}{l}\text { Comitato di Bioetica della Azienda Ospedali Riuniti } \\
\text { di Bergam Largo Barozzi } 1 \\
24128 \text { Bergamo }\end{array}$ \\
\hline v & 1008 & $\begin{array}{l}\text { Comitato Etico ASL di Caserta Via Unità Italiana } \\
2881100 \text { Caserta }\end{array}$ \\
\hline aly & 1009 & $\begin{array}{l}\text { Comitato Etico Dell'Azienda Ospedaliera } \\
\text { Universitaria 'S. Martin' di Genova Largo Rosanna } \\
\text { Benzi } 1016132 \text { Genova }\end{array}$ \\
\hline aly & 1 & $\begin{array}{l}\text { Comitato Etico Della Provincia di Modena Via } \\
\text { Largo del Pozzo } 7141124 \text { Modena }\end{array}$ \\
\hline & 1011 & $\begin{array}{l}\text { Comitato Etico ASL CE/1 Di Caserta Via Unità } \\
\text { Italiana } 2881100 \text { Caserta }\end{array}$ \\
\hline aly & 1012 & $\begin{array}{l}\text { Comitato Etico Regionale Unico (CERU) AOU } \\
\text { Santa Maria della Misericordia Piazzale Santa } \\
\text { maria della Misericordia } 1533100 \text { Udine }\end{array}$ \\
\hline aly & 1013 & $\begin{array}{l}\text { Comitato Etico Scientifico Dell'Azienda Ospedaliera } \\
\text { Ospedale S. Carlo Borromeo di Milano } \\
\text { Via Pio II } n^{\circ} 320153 \text { Milano }\end{array}$ \\
\hline caly & 1014 & $\begin{array}{l}\text { Comitato Bioetico Dell'Azienda Cannizzaro di } \\
\text { Catania Via Messina } 829 \\
95126 \text { Catania }\end{array}$ \\
\hline caly & 1016 & $\begin{array}{l}\text { Comitato Ethico-Scientifico Dell'Azienda } \\
\text { Ospedaliera Ospedale Niguara Ca' Granda Di } \\
\text { Milano Piazza Ospedale Maggiore n. } 320162 \text { Milano }\end{array}$ \\
\hline taly & 1017 & $\begin{array}{l}\text { Comitato Etico Della AUSL RM/H Di Albano Laziale } \\
\text { Borgo Garibaldi n. } 1200041 \text { Albano Laziale (RM) }\end{array}$ \\
\hline
\end{tabular}


Table 3 FIND-CKD trial: Ethics Committee approvals (Continued)

\begin{tabular}{|c|c|c|}
\hline Italy & 1018 & $\begin{array}{l}\text { Comitato Etico Dell'Azienda Ospedaliera Pugliese- } \\
\text { Ciaccio Di Catanzaro } \\
\text { Via Vinicio Cortese, } 1088100 \text { Catanzaro }\end{array}$ \\
\hline Italy & 1020 & $\begin{array}{l}\text { Comitato Etico Dell'Azienda Ospedaliera } \\
\text { Universitaria S. Giovanni Battista di Torino C } \\
\text { so Bramante 88/90 } 10126 \text { Torino }\end{array}$ \\
\hline Italy & 1021 & $\begin{array}{l}\text { Comitato Etico Scientifico Dell'Azienda } \\
\text { Ospedaliera } \\
\text { Ospedale S. Carlo Borrome di Milano } \\
\text { Via Pio } I^{\circ} \text {, n³ } 20153 \text { Milano }\end{array}$ \\
\hline Italy & 1022 & $\begin{array}{l}\text { Comitato Etico Central Dell'IRCCS Fondazione } \\
\text { Salvatore Maugeri Di Pavia Via Salvatore Maugeri } \\
427100 \text { Pavia }\end{array}$ \\
\hline
\end{tabular}

Italy $\quad 1023$ Comitato Etico Sperimentazione clinical Medicinali Della AUSL 8 Di Arezzo Via Curtatone 54 52100 Arezzo

Italy

1024 Comitato Etico

Azienda Ospedaliera Universitaria Ospedali Riuniti di figgia Viale Luigi Pinto 71100 Foggia

Italy $\quad 1026$ Comitato di Etica Della ASL di Salerno Via Federico Ricco, 5084014 Noceria Inferiore (SA)

Italy $\quad 1027$ Comitato Etico Per le Sperimentazioni Cliniche die Medicinali Della Provincia di Venezia Via Don Federico Tosatto 14730174 Venezia

Italy $\quad 1028$ Comitato Etico Della AUSL RM/G di Tivoli Via Tiburtina 22/a 00019 Tivoli (RM)

Italy $\quad 1029$ Comitato Etico Delle Aziende Sanitarie Dell'Umbria di Perugia Via della Rivoluzione 16 Ellera di Corciano (PG) 06070 Perugia

Netherlan 1101 Meander Medical Center, Lichtenberg location ds Toetsingscommissie Wetenschappelijk Onderzoek Secretariat, P\&O Room N042 Utrechtseweg 160 3818 ES Amersfoort The Netherlands

Netherlan 1102 Medical Ethics Review Committee Zuidwest Holland ds Fonteynenburghlaan 7 2275 CX VOORBURG

The Netherlands

Netherlan ds

Netherlan ds

Netherlan ds

1102 Medical Ethics Review Committee Gelre Hospital Albert Schweitzerlaan 31 7334 DZ Apeldoorn The Netherlands

1103 Medical Ethics Review Committee Gelre Hospital Albert Schweitzerlaan 31 7334 DZ Apeldoorn The Netherlands

1104 Medical Ethics Review Committee Albert Schweitzer Hospital loc. DW, Postvak 7, kmr. Z 150

T.a.v. Ms. A. de Graag - de Vries Albert Schweitzerplaats 253318 AT Dordrecht The Netherlands

Netherlan 1105 METc VU Medical Center Medical Faculty, Room ds H-565 Van der Boerchorststraat 7 1081 BT Amsterdam The Netherlands

Netherlan 1106 Medical Ethics Review Committee Noord- Holland ds $\quad$ Foreest Medical School Nassauplein 101815 GM Alkmaar The Netherlands

Norway 1201 Regional Committees for Medical and Health Research Ethics (REK) REK-Midt Bygg for samfunnsmedisin (5 etg) Håkon Jarlsgt. 11, St. Olavs Hospital Trondheim
Table 3 FIND-CKD trial: Ethics Committee approvals (Continued)

\begin{tabular}{|c|c|c|}
\hline Poland & 1301 & $\begin{array}{l}\text { Niezależna Komisja Bioetyczna do Spraw Badań } \\
\text { Naukowych przy Gdańskim Uniwersytecie } \\
\text { Medycznym ul. M. Skłodowskiej-Curie 3a, 80-201 } \\
\text { Gdańsk, Polska }\end{array}$ \\
\hline Poland & 1302 & $\begin{array}{l}\text { Niezależna Komisja Bioetyczna do Spraw Badań } \\
\text { Naukowych przy Gdańskim Uniwersytecie } \\
\text { Medycznym ul. M. Skłodowskiej-Curie 3a, 80-201 } \\
\text { Gdańsk, Polska }\end{array}$ \\
\hline Poland & 1303 & $\begin{array}{l}\text { Niezależna Komisja Bioetyczna do Spraw Badań } \\
\text { Naukowych przy Gdańskim Uniwersytecie } \\
\text { Medycznym ul. M. Skłodowskiej-Curie 3a, 80-201 } \\
\text { Gdańsk, Polska }\end{array}$ \\
\hline
\end{tabular}

Poland 1306 Niezależna Komisja Bioetyczna do Spraw Badań Naukowych przy Gdańskim Uniwersytecie Medycznym ul. M. Skłodowskiej-Curie 3a, 80-201 Gdańsk, Polska

Poland

1309 Niezależna Komisja Bioetyczna do Spraw Badań Naukowych przy Gdańskim Uniwersytecie Medycznym ul. M. Skłodowskiej-Curie 3a, 80-201 Gdańsk, Polska

Poland 1311 Niezależna Komisja Bioetyczna do Spraw Badań Naukowych przy Gdańskim Uniwersytecie Medycznym ul. M. Skłodowskiej-Curie 3a, 80-201 Gdańsk, Polska

Poland 1313 Niezależna Komisja Bioetyczna do Spraw Badań Naukowych przy Gdańskim Uniwersytecie Medycznym ul. M. Skłodowskiej-Curie 3a, 80-201 Gdańsk, Polska

Poland

1314 Niezależna Komisja Bioetyczna do Spraw Badań Naukowych przy Gdańskim Uniwersytecie Medycznym ul. M. Skłodowskiej-Curie 3a, 80-201 Gdańsk, Polska

Poland

1315 Niezależna Komisja Bioetyczna do Spraw Badań Naukowych przy Gdańskim Uniwersytecie Medycznym ul. M. Skłodowskiej-Curie 3a, 80-201 Gdańsk, Polska

Poland

1316 Niezależna Komisja Bioetyczna do Spraw Badań Naukowych przy Gdańskim Uniwersytecie Medycznym ul. M. Skłodowskiej-Curie 3a, 80-201 Gdańsk, Polska

Poland 1318 Niezależna Komisja Bioetyczna do Spraw Badań Naukowych przy Gdańskim Uniwersytecie Medycznym ul. M. Skłodowskiej-Curie 3a, 80-201 Gdańsk, Polska

Poland $\quad 1320 \quad$ Niezależna Komisja Bioetyczna do Spraw Badań Naukowych przy Gdańskim Uniwersytecie Medycznym ul. M. Skłodowskiej-Curie 3a, 80-201 Gdańsk, Polska

Poland $1321 \quad$ Niezależna Komisja Bioetyczna do Spraw Badań Naukowych przy Gdańskim Uniwersytecie Medycznym ul. M. Skłod owskiej-Curie 3a, 80-201 Gdańsk, Polska

Poland 1322 Niezależna Komisja Bioetyczna do Spraw Badań Naukowych przy Gdańskim Uniwersytecie Medycznym ul. M. Skłodowskiej-Curie 3a, 80-201 Gdańsk, Polska

Poland $1323 \quad$ Niezależna Komisja Bioetyczna do Spraw Badań Naukowych przy Gdańskim Uniwersytecie Medycznym ul. M. Skłodowskiej-Curie 3a, 80-201 Gdańsk, Polska 
Table 3 FIND-CKD trial: Ethics Committee approvals (Continued)

\begin{aligned} \hline Poland 1324 & Niezależna Komisja Bioetyczna do Spraw Badań \\ & Naukowych przy Gdańskim Uniwersytecie \\ & Medycznym ul. M. Skłodowskiej-Curie 3a, 80-201 \\ & Gdańsk, Polska \end{aligned}

Poland 1326 Niezależna Komisja Bioetyczna do Spraw Badań Naukowych przy Gdańskim Uniwersytecie Medycznym ul. M. Skłodowskiej-Curie 3a, 80-201 Gdańsk, Polska

Poland 1327 Niezależna Komisja Bioetyczna do Spraw Badań Naukowych przy Gdańskim Uniwersytecie Medycznym ul. M. Skłodowskiej-Curie 3a, 80-201 Gdańsk, Polska

Poland 1328 Niezależna Komisja Bioetyczna do Spraw Badań Naukowych przy Gdańskim Uniwersytecie Medycznym ul. M. Skłodowskiej-Curie 3a, 80-201 Gdańsk, Polska

Poland

1329 Niezależna Komisja Bioetyczna do Spraw Badań Naukowych przy Gdańskim Uniwersytecie Medycznym ul. M. Skłodowskiej-Curie 3a, 80-201 Gdańsk, Polska

Poland $\quad 1330 \quad$ Niezależna Komisja Bioetyczna do Spraw Badań Naukowych przy Gdańskim Uniwersytecie Medycznym ul. M. Skłodowskiej-Curie 3a, 80-201 Gdańsk, Polska

Poland 1331 Niezależna Komisja Bioetyczna do Spraw Badań Naukowych przy Gdańskim Uniwersytecie Medycznym ul. M. Skłodowskiej-Curie 3a, 80-201 Gdańsk, Polska

Portugal 1402 CEIC- National Ethics Committee for Clinical Investigation Parque da Saúde de Lisboa- Avenida do Brasil, 53 1749-004 Lisboa- Portugal

Portugal

1403 CEIC- National Ethics Committee for Clinical Investigation Parque da Saúde de Lisboa- Avenida do Brasil, 53 1749-004 Lisboa- Portugal

Portugal 1404 CEIC- National Ethics Committee for Clinical Investigation Parque da Saúde de Lisboa- Avenida do Brasil, 53 1749-004 Lisboa- Portugal

Portugal 1405 CEIC- National Ethics Committee for Clinical Investigation Parque da Saúde de Lisboa- Avenida do Brasil, 53 1749-004 Lisboa- Portugal

Portugal 1406 CEIC- National Ethics Committee for Clinical Investigation Parque da Saúde de Lisboa- Avenida do Brasil, 53 1749-004 Lisboa- Portugal

Portugal 1407 CElC- National Ethics Committee for Clinical Investigation Parque da Saúde de Lisboa- Avenida do Brasil, 53 1749-004 Lisboa- Portugal

Spain 1501 Hospital Universitario Dr Peset de Valencia CEIC, a/a Raquel E. Blesa, C/Juan de Garray 21, 1er Piso Consultas externas, 46017 Valencia

Spain 1503 Hospital Universitario Dr Peset de Valencia CEIC, a/a Raquel E. Blesa, C/Juan de Garray 21, 1er Piso Consultas externas, 46017 Valencia

Spain

1504 CEIC Hospital Universitario La Paz(LEC) Paseo de la Castellana, 261, Planta 8a Hospital General, 28046 Madrid

Spain 1505 CEIC Fundació Puigvert IUNA (LEC) Agencia de Gestio del Coneixement Cartagena, 340-350 08025 Barcelona
Table 3 FIND-CKD trial: Ethics Committee approvals (Continued)

\begin{tabular}{|c|c|c|}
\hline Spain & 1506 & $\begin{array}{l}\text { CEIC Hospital Universitario General Gregorio } \\
\text { Marañón (CEC) CEIC Area 1, C/ dr Esquerdo, 46, } \\
28007 \text { Madrid }\end{array}$ \\
\hline Spain & 1507 & $\begin{array}{l}\text { Agencia de Ensayos Clinicos - servicio de Farmacia } \\
\text { Hospital Clinic de Barcelona, c/ Villarroel, } 170 \text { - } \\
\text { Sotano, Escalera 6b, } 08036 \text { Barcelona }\end{array}$ \\
\hline Spain & 1509 & $\begin{array}{l}\text { CEIC Hospital Universitario de Bellvitge Edificio } \\
\text { Consultas Externas. Planta -1, C/ Feixa Llarga, s/n, } \\
08907 \text { L'Hospitalet de Llobregat, Barcelona }\end{array}$ \\
\hline
\end{tabular}

Spain $\quad 1510$ CEIC Hospital Universitari Vall d'Hebron Edifici Institut de Recerca, 2a planta Passeig Vall d'Hebron 119-129, Barcelona 08035

Spain 1512 CEIC Hospital Universitario Fundación de Alcorcón (LEC) C/ Budapest N1, 28922 Alcorcon, Madrid

Spain 1513 CEIC Clinica de Asturias Hospital Central de Asturias, Celestino Villamil, s/n, 33006 Oviedo

Spain 1514 Hopsital Universitario "Reina Sofia" Comite Etico de Ensayos Clinicos, Edificio de Consultas Externas, planta -1, Avda. Menendez Pidal, s/n, 14004 Cordoba

Spain $\quad 1515$ Hospital Torrecardenas CEIC Paraje Torrecardenas, s/n, 04009 Almeria

Spain 1516 Fundacion Jimenez Diaz CEIC, Avda. Reyes Catolicos, 2, Entrplanta, 28040 Madrid

Spain 1517 Hospital Universitario Principe de Asturias CEIC, Ctra. Alcala-Meco s/n, 28805 Alcala de Henares, Madrid

Spain 1518 CElC de Aragon, Avda. Gomez Laguna, 25 planta 11, 50009 Zaragoza

Spain 1519 Hospital Universitario de Puerto Real, Ctra. Nal IV, km. 665, 11510 Puerto Real, Cadiz

Spain $\quad 1520$ CEIC Hospital Universitario de Getafe (LEC) Ctra. De Toledo, km. 12500, 28905 Getafe, Madrid

Spain $\quad 1521$ CEIC Hospital Universitario La Princesa, Findacion para la Investigacion Biomedica, C/ Diego de leon, 62, 28006 Madrid

Spain $\quad 1522$ CEIC Hospital Universitario de Girona Josep Trueta (LEC) avda. De Franca s/n, 17007 Girona

Spain 1523 CEIC Parc Salut del Mar (LEC) IMIM-Hospital del Mar, Parc de Recerca Biomedica de Barcelona, Doctor Aiguader, 88, 08003 Barcelona

Sweden 1601 Regionala etikprövningsnämnden Stockholm FE 289 Karolinska Institutet Stockholm, 17179

Sweden 1602 Regionala etikprövningsnämnden Stockholm FE 289 Karolinska Institutet Stockholm, 17179

Sweden 1603 Regionala etikprövningsnämnden Stockholm FE 289 Karolinska Institutet Stockholm, 17179

Switzerland 1701 Kantonal Ethikkommission Aargau Departement Gesundheit und Soziales PD Dr. med. Otto Hilfiker Bachstrasse 15 5001 Aarau 
Table 3 FIND-CKD trial: Ethics Committee approvals (Continued)

\begin{tabular}{|c|c|c|}
\hline $\begin{array}{l}\text { Switzerlan } \\
\text { d }\end{array}$ & 1702 & $\begin{array}{l}\text { Kantonal Ethik-Kommission (KEK) Prof. Dr. med. } \\
\text { Robert Maurer Universitätsspital Zürich Sonneggstr } \\
128091 \text { Zürich }\end{array}$ \\
\hline $\begin{array}{l}\text { Switzerlan } \\
\text { d }\end{array}$ & 1703 & $\begin{array}{l}\text { Kantonal Ethik-Kommission (KEK) Prof. Dr. med. } \\
\text { Robert Maurer Universitätsspital Zürich } \\
\text { Sonneggstr. } 128091 \text { Zürich }\end{array}$ \\
\hline $\begin{array}{l}\text { Switzerlan } \\
\text { d }\end{array}$ & 1704 & $\begin{array}{l}\text { Kantonal Ethikkommission Bern (KEK) Prof. Dr. } \\
\text { pharm. Nilaus Tüller Postfach } 563 \text { Bern }\end{array}$ \\
\hline Turkey & 1801 & $\begin{array}{l}\text { Ankara University Medical Faculty Deanship } \\
\text { Clinical Researches Ethics Committee nkara } \\
\text { Universitesi Tip Fakultesi Morfoloji Binası } 06100 \\
\text { Sihhiye Ankara Turkey }\end{array}$ \\
\hline
\end{tabular}

1802 Ege University Medical Faculty Clinical Researches Ethics Committee Ege Universitesi Tip Fakultesi; 35100 Bornova Izmir

Turkey $\quad 1803$ Ege University Medical Faculty Clinical Researches Ethics Committee Ege Universitesi Tip Fakultesi; 35100 Bornova Izmir

Turkey 1804 Ege University Medical Faculty Clinical Researches Ethics Committee Ege Universitesi Tip Fakultesi; 35100 Bornova Izmir

1804 Ege University Medical Faculty Clinical Researches Ethics Committee Ege Universitesi Tip Fakultesi; 35100 Bornova Izmir

Turkey 1807 Ege University Medical Faculty Clinical Researches Ethics Committee Ege Universitesi Tip Fakultesi; 35100 Bornova Izmir

Turkey 1810 Ege University Medical Faculty Clinical Researches Ethics Committee Ege Universitesi Tip Fakultesi; 35100 Bornova Izmir

Turkey $\quad 1811$ Ege University Medical Faculty Clinical Researches Ethics Committee Ege Universitesi Tip Fakultesi; 35100 Bornova Izmir

United Kingdom

1901 Health Research Authority NRES Committee Riverside REC Bristol REC Centre Level 3, Block B Whitefriars Lewins Mead Bristol, BS 1 2NT

United

Kingdom

1902 Health Research Authority NRES Committee Riverside REC Bristol REC Centre Level 3, Block B Whitefriars Lewins Mead Bristol, BS 1 2NT

United

Kingdom

1903 Health Research Authority NRES Committee Riverside REC Bristol REC Centre Level 3, Block B Whitefriars Lewins Mead Bristol, BS 1 2NT

United Kingdom

United

Kingdom

1905 Health Research Authority NRES Committee Riverside REC Bristol REC Centre Level 3, Block B Whitefriars Lewins Mead Bristol, BS 1 2NT

United

Kingdom

1906 Health Research Authority NRES Committee Riverside REC Bristol REC Centre Whitefriars, Lewins Mead

United Kingdom
1907 Health Research Authority NRES Committee Riverside REC Bristol REC Centre
Table 3 FIND-CKD trial: Ethics Committee approvals (Continued)

\begin{tabular}{|c|c|c|}
\hline & & Whitefriars, Lewins Mead \\
\hline $\begin{array}{l}\text { United } \\
\text { Kingdom }\end{array}$ & 1908 & $\begin{array}{l}\text { Health Research Authority } \\
\text { NRES Committee Riverside REC } \\
\text { Bristol REC Centre } \\
\text { Whitefriars, Lewins Mead }\end{array}$ \\
\hline $\begin{array}{l}\text { United } \\
\text { Kingdom }\end{array}$ & 1909 & $\begin{array}{l}\text { Health Research Authority } \\
\text { NRES Committee Riverside REC } \\
\text { Bristol REC Centre } \\
\text { Whitefriars, Lewins Mead }\end{array}$ \\
\hline $\begin{array}{l}\text { United } \\
\text { Kingdom }\end{array}$ & 1910 & $\begin{array}{l}\text { Health Research Authority } \\
\text { NRES Committee Riverside REC } \\
\text { Bristol REC Centre } \\
\text { Whitefriars, Lewins Mead }\end{array}$ \\
\hline $\begin{array}{l}\text { Inited } \\
\text { ingdom }\end{array}$ & 1911 & $\begin{array}{l}\text { Health Research Authority } \\
\text { NRES Committee Riverside REC } \\
\text { Bristol REC Centre } \\
\text { Whitefriars, Lewins Mead }\end{array}$ \\
\hline $\begin{array}{l}\text { United } \\
\text { Kingdom }\end{array}$ & 1912 & $\begin{array}{l}\text { Health Research Authority } \\
\text { NRES Committee Riverside REC } \\
\text { Bristol REC Centre } \\
\text { Whitefriars, Lewins Mead }\end{array}$ \\
\hline $\begin{array}{l}\text { United } \\
\text { Kingdom }\end{array}$ & 1913 & $\begin{array}{l}\text { Health Research Authority } \\
\text { NRES Committee Riverside REC } \\
\text { Bristol REC Centre } \\
\text { Whitefriars, Lewins Mead }\end{array}$ \\
\hline $\begin{array}{l}\text { United } \\
\text { Kingdom }\end{array}$ & 1914 & $\begin{array}{l}\text { Health Research Authority } \\
\text { NRES Committee Riverside REC } \\
\text { Bristol REC Centre } \\
\text { Whitefriars, Lewins Mead }\end{array}$ \\
\hline $\begin{array}{l}\text { United } \\
\text { Kingdom }\end{array}$ & 1915 & $\begin{array}{l}\text { Health Research Authority } \\
\text { NRES Committee Riverside REC } \\
\text { Bristol REC Centre } \\
\text { Whitefriars, Lewins Mead }\end{array}$ \\
\hline $\begin{array}{l}\text { United } \\
\text { Kingdon }\end{array}$ & 1916 & $\begin{array}{l}\text { Health Research Authority } \\
\text { NRES Committee Riverside REC } \\
\text { Bristol REC Centre } \\
\text { Whitefriars, Lewins Mead }\end{array}$ \\
\hline
\end{tabular}

United

Kingdom

1917 Health Research Authority NRES Committee Riverside REC Bristol REC Centre Level 3, Block B Whitefriars Lewins Mead Bristol, BS 1 2NT

United

Kingdom

1918 Health Research Authority NRES Committee Riverside REC Bristol REC Centre Level 3, Block B Whitefriars Lewins Mead Bristol, BS 1 2NT

United

Kingdom

1919 Health Research Authority NRES Committee Riverside REC Bristol REC Centre Level 3, Block B Whitefriars Lewins Mead Bristol, BS 1 2NT

United

Kingdom

1920 Health Research Authority NRES Committee Riverside REC Bristol REC Centre Level 3, Block B Whitefriars Lewins Mead Bristol, BS 1 2NT

United

Kingdom

1921 Health Research Authority NRES Committee Riverside REC Bristol REC Centre Level 3, Block B Whitefriars Lewins Mead Bristol, BS 1 2NT

United Kingdom

1922 Health Research Authority NRES Committee Riverside REC Bristol REC Centre Level 3, Block B Whitefriars Lewins Mead Bristol, BS 1 2NT 
Table 3 FIND-CKD trial: Ethics Committee approvals (Continued)

\begin{tabular}{|c|c|c|c|c|c|}
\hline $\begin{array}{l}\text { United } \\
\text { Kingdom }\end{array}$ & 1923 & $\begin{array}{l}\text { Health Research Authority NRES Committee } \\
\text { Riverside REC Bristol REC Centre } \\
\text { Level 3, Block B Whitefriars Lewins Mead Bristol, } \\
\text { BS } 1 \text { 2NT }\end{array}$ & Romania & 2005 & $\begin{array}{l}\text { National Ethics Committee for Clinical Study of } \\
\text { Medicine (Comisia Nationala de Etica pentru } \\
\text { Studiul Clinic al Medicamentului) Av. Sanatescu } \\
\text { St., No. 48, 1st district, 011478, Bucharest, Romania }\end{array}$ \\
\hline $\begin{array}{l}\text { United } \\
\text { Kingdom }\end{array}$ & 1924 & $\begin{array}{l}\text { Health Research Authority NRES Committee } \\
\text { Riverside REC Bristol REC Centre } \\
\text { Level 3, Block B Whitefriars Lewins Mead Bristol, } \\
\text { BS } 1 \text { 2NT }\end{array}$ & Romania & 2006 & $\begin{array}{l}\text { National Ethics Committee for Clinical Study of } \\
\text { Medicine (Comisia Nationala de Etica pentru } \\
\text { Studiul Clinic al Medicamentului) Av. Sanatescu } \\
\text { St., No. 48, 1st district, 011478, Bucharest, Romania }\end{array}$ \\
\hline $\begin{array}{l}\text { United } \\
\text { Kingdom }\end{array}$ & 1925 & $\begin{array}{l}\text { Health Research Authority NRES Committee } \\
\text { Riverside REC Bristol REC Centre } \\
\text { Level 3, Block B Whitefriars Lewins Mead Bristol, } \\
\text { BS } 1 \text { 2NT }\end{array}$ & Romania & 2007 & $\begin{array}{l}\text { National Ethics Committee for Clinical Study of } \\
\text { Medicine (Comisia Nationala de Etica pentru } \\
\text { Studiul Clinic al Medicamentului) Av. Sanatescu } \\
\text { St., No. 48, 1st district, 011478, Bucharest, Romania }\end{array}$ \\
\hline \multirow[t]{2}{*}{$\begin{array}{l}\text { United } \\
\text { Kingdom }\end{array}$} & \multirow[t]{2}{*}{1926} & \multirow{2}{*}{$\begin{array}{l}\text { Health Research Authority NRES Committee } \\
\text { Riverside REC Bristol REC Centre } \\
\text { Level 3, Block B Whitefriars Lewins Mead Bristol, } \\
\text { BS } 1 \text { 2NT }\end{array}$} & US & 2110 & $\begin{array}{l}\text { Salem VA Medical Center IRB Kim Ragsdale, PhD } \\
1970 \text { Roanoke Blvd } \\
\text { Salem. VA } 24153\end{array}$ \\
\hline & & & US & 2113 & Integreview IRB Valerie Nelson \\
\hline \multirow[t]{2}{*}{$\begin{array}{l}\text { United } \\
\text { Kingdom }\end{array}$} & \multirow[t]{2}{*}{1927} & \multirow{2}{*}{$\begin{array}{l}\text { Health Research Authority NRES Committee } \\
\text { Riverside REC Bristol REC Centre } \\
\text { Level 3, Block B Whitefriars Lewins Mead Bristol, } \\
\text { BS } 1 \text { 2NT }\end{array}$} & & & $\begin{array}{l}\text { 3001, South Lamar Blvd Suite } 210 \text { Austin, } \\
\text { TX } 78704\end{array}$ \\
\hline & & & US & 2105 & $\begin{array}{l}\text { Integreview IRB Valerie Nelson } \\
\text { 3001, South Lamar Blvd Suite } 210 \text { Austin, }\end{array}$ \\
\hline \multirow{2}{*}{$\begin{array}{l}\text { United } \\
\text { Kingdom }\end{array}$} & \multirow[t]{2}{*}{1928} & \multirow{2}{*}{$\begin{array}{l}\text { Health Research Authority NRES Committee } \\
\text { Riverside REC Bristol REC Centre } \\
\text { Level 3, Block B Whitefriars Lewins Mead Bristol, } \\
\text { BS } 1 \text { 2NT }\end{array}$} & & & TX 78704 \\
\hline & & & US & 2114 & $\begin{array}{l}\text { Temple VA Medical Cener IRB John W Klocek, } \\
\text { PhD } 1901 \text { Veterans Memorial Drive Temple, } \\
\text { TX } 76504\end{array}$ \\
\hline
\end{tabular}

United 1929 Health Research Authority NRES Committee

Kingdom Riverside REC Bristol REC Centre Level 3, Block B Whitefriars Lewins Mead Bristol, BS 1 2NT

United

Kingdom

19230 Health Research Authority NRES Committee Riverside REC Bristol REC Centre Level 3, Block B Whitefriars Lewins Mead Bristol, BS 1 2NT

United

Kingdom

1931 Health Research Authority NRES Committee Riverside REC Bristol REC Centre Level 3, Block B Whitefriars Lewins Mead Bristol, BS 1 2NT

United

Kingdom

United

Kingdom

Romania 2001 National Ethics Committee for Clinical Study of Medicine (Comisia Nationala de Etica pentru Studiul Clinic al Medicamentului) Av. Sanatescu St., No. 48, 1st district, 011478, Bucharest, Romania

Romania 2002 National Ethics Committee for Clinical Study of Medicine (Comisia Nationala de Etica pentru Studiul Clinic al Medicamentului) Av. Sanatescu St., No. 48, 1st district, 011478, Bucharest, Romania

Romania 2003 National Ethics Committee for Clinical Study of Medicine (Comisia Nationala de Etica pentru Studiul Clinic al Medicamentului) Av. Sanatescu St., No. 48, 1st district, 011478, Bucharest, Romania

Romania 2004 National Ethics Committee for Clinical Study of Medicine (Comisia Nationala de Etica pentru Studiul Clinic al Medicamentului) Av. Sanatescu St., No. 48, 1st district, 011478, Bucharest, Romania
Table 3 FIND-CKD trial: Ethics Committee approvals (Continued)

\section{Additional files}

Additional file 1: Table S1. Baseline characteristics (ITT population). (DOCX $12 \mathrm{~kb}$ )

Additional file 2: Table S2. Mean (SD) change in estimated GFR (eGFR) from baseline to month 12 for subpopulations of patients with eGFR values both time points. (DOCX $12 \mathrm{~kb}$ )

Additional file 3: Figure S1. Scatter plot of change in eGFR from baseline to month 12 according to total IV iron dose in patients randomized to either high ferritin or low ferritin FCM for patients with eGFR values at baseline and month 12. The solid line indicates the linear regression for all points. The dotted line indicates 0 i.e. no change. eGFR, estimated glomerular filtration rate; FCM, ferric carboxymaltose. (EPS $1219 \mathrm{~kb}$ )

Additional file 4: Figure S2. (a) Ferritin and (b) transferrin saturation (TSAT) for patients with eGFR values at baseline and month 12 who did or did not receive alternative anemia therapy or permanently discontinued study therapy before month 12. BL, baseline; FCM, ferric carboxymaltose. (ZIP $456 \mathrm{~kb}$ )

Additional file 5: Table S3. Selected renal adverse events and serious adverse events (safety population). (DOCX $11 \mathrm{~kb}$ )

ACE: Angiotensin converting enzyme; ANCOVA: Analysis of covariance; ARB: Angiotensin II receptor blocker; BMI: Body mass index; CKD: Chronic kidney disease; CKD-EPI: Chronic Kidney Disease Epidemiology Collaboration; eGFR: estimated GFR; ESA: Erythropoiesis-stimulating agent; FCM: Ferric carboxymaltose; ITT: Intention-to-treat; IV: Intravenous; MDA: Malondialdehyde; MDRD: Modification of Diet in Renal Disease; ND-CKD: Non-dialysis dependent CKD; NTBI: Non-transferrin bound iron; TSAT: Transferrin saturation

\section{Acknowledgments}

The FIND-CKD study was funded by Vifor Pharma, Glattbrugg, Switzerland. Medical writing supported was provided by a freelance medical writer funded by Vifor Pharma (C Dunstall). The study was designed, implemented and overseen by members of the FIND-CKD Steering Committee and a Data and Safety Monitoring

\section{Abbreviations}


Board together with representatives of the study sponsor. On-site monitoring, data collection and data management were performed by ICON Clinical Research (Dublin, Ireland). Data analysis was performed by a biostatistician in ICON with oversight and validation by the sponsor statistician (B Roubert) according to a predefined statistical analysis plan which was reviewed by an independent statistician. All authors had full access to the study data, decided to submit the report for publication, assume responsibility for the completeness and accuracy of the data, and the content and integrity of the report.

Members of the Ferinject assessment in patients with Iron deficiency anemia and Non-Dialysis dependent Chronic Kidney Disease (FIND-CKD) study group are listed in Appendix 1.

\section{Availability of data and materials}

Data relating to the primary FIND-CKD study analysis can be obtained at: https://clinicaltrials.gov/ct2/show/NCT00994318?term=FIND+CKD\&rank=1.All source data for the current analysis are available from the authors. Requests may be emailed to: iain.macdougall@nhs.net.

\section{Authors' contributions}

ICM, AHB, FC, K-UE, CG, DW and SDR contributed to the study design, recruited patients and collected data during the study. ICM developed the first draft of the manuscript, which was critically reviewed, revised and approved by the other authors. YM provided clinical support. SL was the study statistician. All authors read and approved the final manuscript.

\section{Competing interests}

lain C Macdougall has received speaker's fees, honoraria and consultancy fees from several manufacturers of ESAs and IV iron, including Affymax, AMAG, Amgen, Ortho Biotech, Pharmacosmos, Hoffmann-La Roche, Takeda and Vifor Pharma. Andreas H. Bock has received speaker's honoraria and consultancy fees from Amgen, Hoffmann-La Roche and Vifor Pharma. Fernando Carrera has no conflicts of interest to declare. Kai-Uwe Eckardt has received speaker's fees and/ or consultancy fees from manufacturers of ESAs and IV iron, including Affymax, Amgen, Bayer, Johnson \& Johnson, Hoffmann-La Roche and Vifor Pharma. Carlo Gaillard has received speaker's fees, honoraria and consultancy fees from manufacturers of ESAs and IV iron, including Amgen, Pharmacosmos, Hoffmann-La Roche, Takeda and Vifor Pharma. David Van Wyck is an employee and stockholder of DaVita Healthcare Partners, Inc. Yvonne Meier and Sylvain Larroque are employees of Vifor Pharma. Simon D Roger has received speaker's fees, honoraria and consultancy fees from several manufacturers of ESAs and IV iron, including Amgen, Hoffmann-La Roche, Janssen-Cilag, Novartis, Sandoz, Takeda and Vifor Pharma.

\section{Consent for publication}

No individual data are presented.

\section{Ethics approval and consent to participate}

The study was conducted according to the principles of the Declaration of Helsinki and the ICH Guidelines for Good Clinical Practice. All patients provided written informed consent. The study protocol was approved at all participating sites (see Appendix 2 for a list of Ethics Committees).

\section{Author details}

'Department of Renal Medicine, King's College Hospital, Denmark Hill, London SE5 9RS, UK. ²Department of Nephrology, Kantonsspital Aarau, Aarau, Switzerland. ${ }^{3}$ Eurodial, DaVita, Leiria, Portugal. ${ }^{4}$ Department of Nephrology and Hypertension, University of Erlangen-Nürnberg, Erlangen, Germany. ${ }^{5}$ Department of Nephrology, University Medical Center Groningen, University of Groningen, Groningen, The Netherlands. ${ }^{6}$ DaVita Healthcare Partners Inc., Denver, CO, USA. Vifor Pharma, Glattbrugg, Switzerland. ${ }^{8}$ Renal Research, Gosford, NSW, Australia.

Received: 20 May 2016 Accepted: 10 January 2017

Published online: 17 January 2017

\section{References}

1. Freburger JK, Ng LJ, Bradbury BD, Kshirsagar AV, Brookhart MA. Changing patterns of anemia management in US hemodialysis patients. Am J Med. 2012;125:906-14.

2. Unger EG, Thompson AM, Blank MJ, Temple R. Erythropoiesis-stimulating agents - time for a reevaluation. New Engl J Med. 2010;362:189-92.
3. Solomon SE, Uno H, Lewis EF, Eckardt KU, Lin J, Burdmann EA, de Zeeuw D, Ivanovich P, Levey AS, Parfrey P, Remuzzi G, Singh AK, Toto R, Huang F, Rossert J, McMurray JJ, Pfeffer MA. Trial to Reduce Cardiovascular Events with Aranesp Therapy (TREAT) Investigators. Erythropoietic response and outcomes in kidney disease and type 2 diabetes. N Engl J Med. 2010;363: 1146-55.

4. Macdougall IC, Tucker B, Thompson J, Tomson CR, Baker LR, Raine AE. A randomized controlled study of iron supplementation in patients treated with erythropoietin. Kidney Int. 1996;50:1694-9.

5. Li H, Wang SX. Intravenous iron sucrose in Chinese hemodialysis patients with renal anemia. Blood Purif. 2008;26:151-6.

6. Warady BA, Kausz A, Lerner G, Brewer ED, Chadha V, Brugnara C, Dahl NV, Watkins SL. Iron therapy in the pediatric hemodialysis population. Pediatr Nephrol. 2004;19:655-61.

7. Qunibi WY, Martinez C, Smith M, Benjamin J, Mangione A, Roger SD. A randomised controlled trial comparing intravenous ferric carboxymaltose with oral iron for treatment of iron deficiency anaemia of non-dialysisdependent chronic kidney disease patients. Nephrol Dial Transplant. 2011; 26:1599-607.

8. Charytan C, Qunibi W, Bailie GR, Venofer Clinical Studies Group. Comparison of intravenous iron sucrose to oral iron in the treatment of anemic patients with chronic kidney disease not on dialysis. Nephron Clin Pract. 2005;100: c55-62.

9. Spinowitz BS, Kausz AT, Baptista J, Noble SD, Sothinathan R, Bernardo MV, Brenner L, Pereira BJ. Ferumoxytol for treating iron deficiency anemia in CKD. J Am Soc Nephrol. 2008;19:1599-605.

10. Van Wyck DB, Roppolo M, Martinez CO, Mazey RM, McMurray S, United States Iron Sucrose (Venofer) Clinical Trials Group. A randomized, controlled trial comparing IV iron sucrose to oral iron in anemic patients with nondialysis-dependent CKD. Kidney Int. 2005;68:2846-56.

11. Charytan C, Bernardo MV, Koch TA, Butcher A, Morris D, Bregman DB. Intravenous ferric carboxymaltose versus standard medical care in the treatment of iron deficiency anemia in patients with chronic kidney disease: a randomized, active-controlled, multi-center study. Nephrol Dial Transplant. 2013;28:953-64.

12. Macdougall IC, Bock AH, Carrera F, Eckardt KU, Gaillard C, Van Wyck D, Roubert B, Nolen JG, Roger SD, FIND-CKD Study Investigators. FIND-CKD: a randomized trial of intravenous ferric carboxymaltose versus oral iron in patients with chronic kidney disease and iron deficiency anaemia. Nephrol Dial Transplant. 2014:29:2075-84.

13. Bishu K, Agarwal R. Acute injury with intravenous iron and concerns regarding long-term safety. Clin Am J Soc Nephrol. 2006;1 Suppl 1:S19-23.

14. Zanen AL, Adriaansen HJ, van Bommel EF, Posthuma R, de Jong GMT. 'Oversaturation' of transferrin after intravenous iron gluconate (Ferrlecit') in haemodialysis patients. Nephrol Dial Transplant. 1996;11:820-4.

15. Pai AB, Conner T, McQuade CR, Olp J, Hicks P. Non-transferrin bound iron, cytokine activation and intracellular reactive oxygen species generation in hemodialysis patients receiving intravenous iron dextran or iron sucrose. Biometals. 2011:24:603-13.

16. Johnson AC, Becker $\mathrm{K}$, Zager RA. Parenteral iron formulations differentially affect MCP-1, HO-1, and NGAL gene expression and renal responses to injury. Am J Physiol Renal Physiol. 2010;299:F426-35.

17. Toblli JE, Cao G, Olivieri L, Angerosa M. Comparison of the renal, cardiovascular and hepatic toxicity data of original intravenous iron compounds. Nephrol Dial Transplant. 2010;25:3631-40.

18. Toblli JE, Cao G, Giani JF, Dominici FP, Angerosa M. Nitrosative stress and apoptosis by intravenous ferumoxytol, iron isomaltoside 1000, iron dextran, iron sucrose, and ferric carboxymaltose in a nonclinical model. Drug Res (Stuttg). 2015:65:354-60.

19. Agarwal R, Leehey DJ, Olsen SM, Dahl NV. Proteinuria induced by parenteral iron in chronic kidney disease-a comparative randomized controlled trial. Clin J Am Soc Nephrol. 2011;6:114-21.

20. Agarwal R, Rizkala AR, Kaskas MO, Minasian R, Trout JR. Iron sucrose causes greater proteinuria than ferric gluconate in non-dialysis chronic kidney disease. Kidney Int. 2007;72:638-42.

21. Leehey DJ, Palubiak DJ, Chebrolu S, Agarwal R. Sodium ferric gluconate causes oxidative stress but not acute renal injury in patients with chronic kidney disease: a pilot study. Nephrol Dial Transplant. 2005;20:135-40.

22. Agarwal R, Vasavada N, Sachs NG, Chase S. Oxidative stress and renal injury with intravenous iron in patients with chronic kidney disease. Kidney Int. 2004;65:2279-89. 
23. Agarwal R. On the nature of proteinuria with acute renal injury in patients with chronic kidney disease. Am J Physiol Renal Physiol. 2005;288:F265-71.

24. Agarwal R, Kusek JW, Pappas MK. A randomized trial of intravenous and oral iron in chronic kidney disease. Kidney Int. 2015;88:905-14.

25. Macdougall IC, Bock A, Carrera F, Eckardt KU, Gaillard C, Van Wyck D, Roubert B, Cushway T, Roger SD, FIND-CKD Study Investigators. The FINDCKD study-a randomized controlled trial of intravenous iron versus oral iron in non-dialysis chronic kidney disease patients: background and rationale. Nephrol Dial Transplant. 2014;29:843-50.

26. Levey AS, Bosch JP, Lewis JB, Greene T, Rogers N, Roth D. A more accurate method to estimate glomerular filtration rate from serum creatinine: a new prediction equation. Modification of Diet in Renal Disease Study Group. Ann Intern Med. 1999;130:461-70.

27. Levey AS, Stevens LA, Schmid CH, Zhang YL, Castro 3rd AF, Feldman HI, Kusek JW, Eggers P, Van Lente F, Greene T, Coresh J, CKD-EPI (Chronic Kidney Disease Epidemiology Collaboration). A new equation to estimate glomerular filtration rate. Ann Intern Med. 2009:150:604-12.

28. Levey AS, Inker LA, Coresh J. GFR estimation: from physiology to public health. Am J Kidney Dis. 2014;63:820-34.

29. McMahon LP, Kent AB, Kerr PG, Healy H, Irish AB, Cooper B, Kark A, Roger $S D$. Maintenance of elevated versus physiological iron indices in nonanaemic patients with chronic kidney disease: a randomized controlled trial. Nephrol Dial Transplant. 2010;25:920-6.

30. Malindretos P, Sarafidis PA, Redenco I, Raptis V, Makedou K, Makedou A, Grekas DM. Slow intravenous iron administration does not aggravate oxidative stress and inflammatory biomarkers during hemodialysis: a comparative study between iron sucrose and iron dextran. Am J Nephrol. 2007;27:572-9.

\section{Submit your next manuscript to BioMed Central and we will help you at every step:}

- We accept pre-submission inquiries

- Our selector tool helps you to find the most relevant journal

- We provide round the clock customer support

- Convenient online submission

- Thorough peer review

- Inclusion in PubMed and all major indexing services

- Maximum visibility for your research

Submit your manuscript at www.biomedcentral.com/submit 